\title{
Ground-Water Resources of Okeechobee County, Florida
}

By L.A. Bradner

U.S. GEOLOGICAL SURVEY

Water-Resources Investigations Report 92-4166

Prepared in cooperation with the

SOUTH FLORIDA WATER MANAGEMENT DISTRICT 


\title{
U.S. DEPARTMENT OF THE INTERIOR BRUCE BABBITT, Secretary
}

\author{
U.S. GEOLOGICAL SURVEY \\ GORDON P. EATON, Director
}

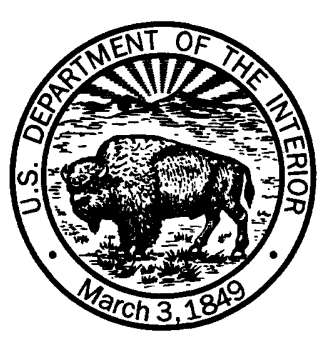

Any use of trade, product, or firm names in this publication is for identification purposes only and does not constitute endorsement by the U.S. Geological Survey.

For additional information write to:

District Chief

U.S. Geological Survey

Suite 3015

227 North Bronough Street

Tallahassee, Florida 32301
Copies of this report can be purchased from:

U.S. Geological Survey

Earth Science Information Center

Open-File Reports Section

Box 25286, MS 517

Denver Federal Center

Denver, CO 80225 


\section{CONTENTS}

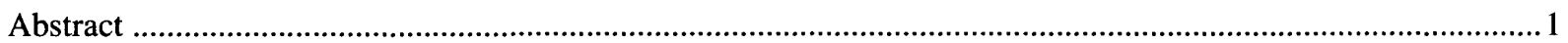

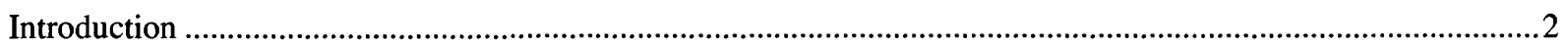

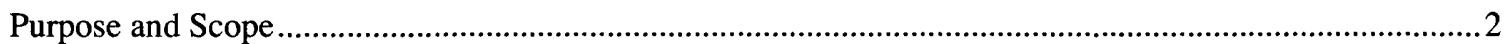

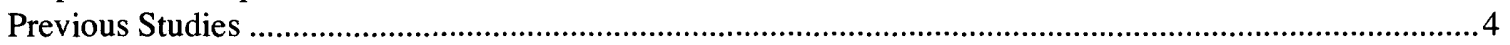

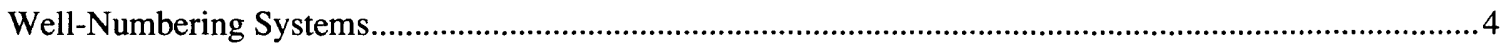

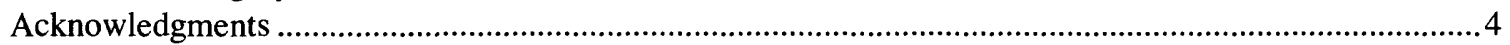

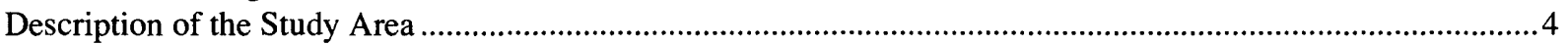

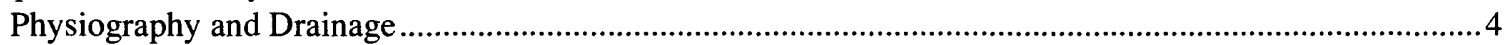

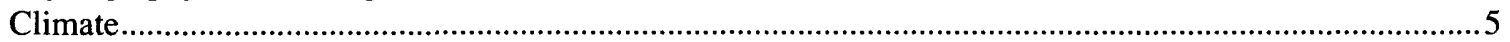

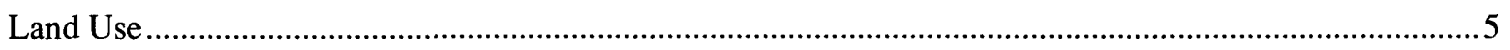

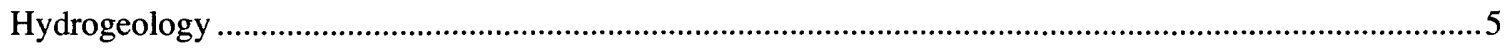

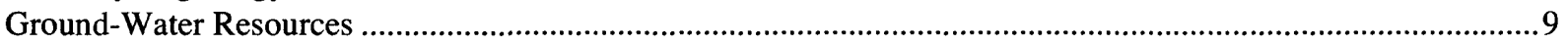

Surficial Aquifer System .................................................................................................................

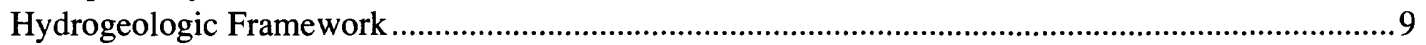

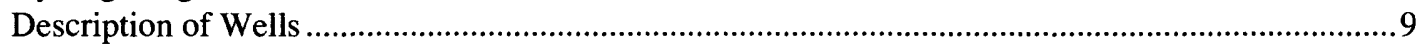

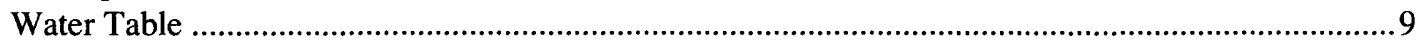

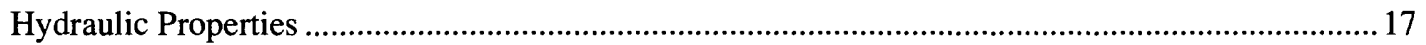

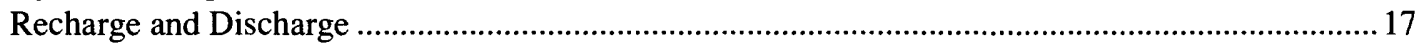

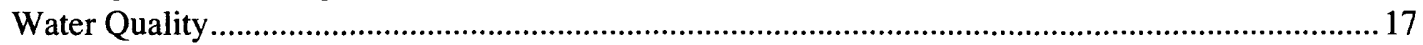

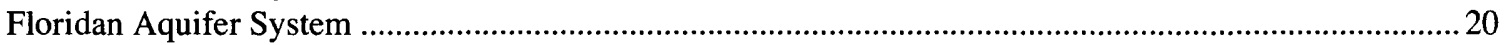

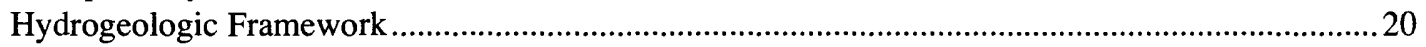

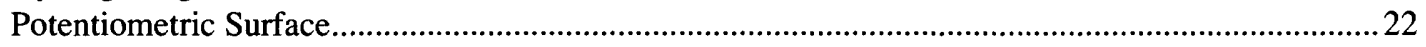

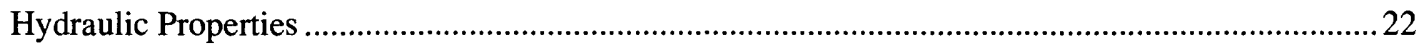

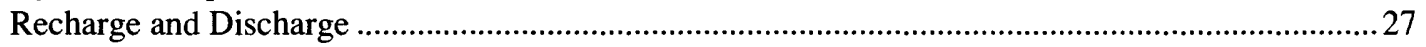

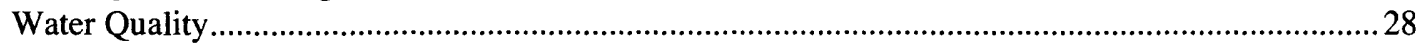

Variations in Chloride Concentration with Depth ................................................................... 33

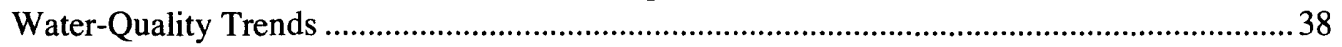

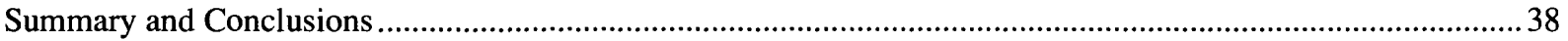

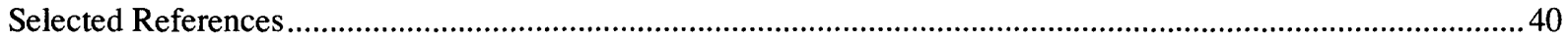

\section{FIGURES}

1. Map showing location of the study area and rainfall-gaging stations ....................................................... 3

2. Map showing Pleistocene marine terraces in the study area ................................................................. 6

3. Graphs showing annual rainfall at Fort Drum $5 \mathrm{NW}, 1957-90$, and at Okeechobee Hurricane Gate 6,

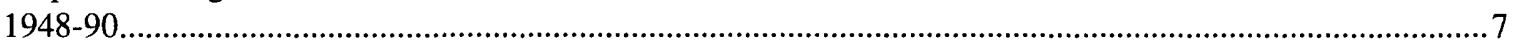

4. Diagram showing description of the hydrogeologic and geologic units in Okeechobee County, Fla.............. 8

5. Map showing locations of wells used for data collection and lines of hydrogeologic section. 12

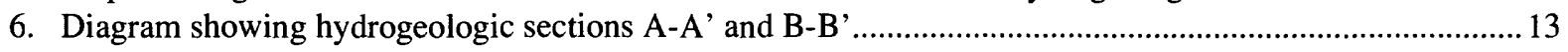

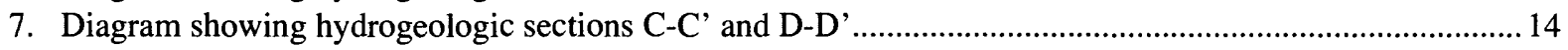

8. Diagram showing gamma-ray log and lithologic description of well 23 .................................................15

9. Map showing thickness of the surficial aquifer system, Okeechobee County, Fla........................................ 16

10. Diagram showing ground-water movement from the Floridan aquifer system to the surficial aquifer system through wells ............................................................................................................................... 19

11. Map showing altitude of and depth to the top of the Floridan aquifer system .............................................21

12. Map showing potentiometric surfaces of the Upper Floridan aquifer for predevelopment and September 1990 and areas of natural discharge from the Floridan aquifer system ........................................23

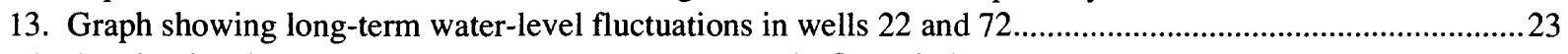

14. Graphs showing results of single-well recovery tests in Okeechobee County, Fla........................................24 
15-18. Maps showing:

15. Transmissivities and specific capacities of the Floridan aquifer system,

Okeechobee County, Fla.

16. Dissolved-solids concentration in water from wells that tap the Upper Floridan aquifer,

Okeechobee County, Fla.

17. Sulfate concentration in water from wells that tap the Upper Floridan aquifer,

Okeechobee County, Fla.

18. Chloride concentrations in water from wells that tap the Upper Floridan aquifer,

Okeechobee County, Fla

19. Graph showing relation between land-surface altitude and chloride concentrations in water from wells that tap the Upper Floridan aquifer, Okeechobee County, Fla

20. Diagram showing chemical composition of water from wells that tap the Floridan aquifer system, Okeechobee County, Fla.

21. Map showing chloride concentrations in water from wells that tap the Upper and Lower Floridan aquifers, Okeechobee County, Fla.

22. Map showing depth to brackish water in the Floridan aquifer system.

23. Graph showing temperature, chloride concentration, and resistivity of water from well 27 that taps the intermediate confining unit and the Upper and Lower Floridan aquifers

24. Graph showing chloride concentrations in water from well 22

\section{TABLES}

1. Wells in the study area used to obtain water-level, water-quality, and geologic data.

2. Quality of water from wells that tap the surficial aquifer system in Okeechobee County, Fla.

3. Transmissivities of the Floridan aquifer system in Okeechobee County, Fla.

4. Quality of water from wells that tap the Upper Foridan aquifer and from wells that tap the Upper and Lower Floridan aquifers in Okeechobee County, Fla., 1990-91 


\begin{tabular}{|c|c|c|}
\hline Multiply & By & To obtain \\
\hline \multicolumn{3}{|c|}{ Length } \\
\hline $\begin{array}{r}\text { inch (in.) } \\
\text { foot (ft) } \\
\text { mile (mi) }\end{array}$ & $\begin{array}{l}25.4 \\
0.3048 \\
1.609\end{array}$ & $\begin{array}{l}\text { millimeter } \\
\text { meter } \\
\text { kilometer }\end{array}$ \\
\hline \multicolumn{3}{|c|}{$\underline{\text { Area }}$} \\
\hline $\begin{array}{r}\text { acre } \\
\text { square mile }\left(\mathrm{mi}^{2}\right)\end{array}$ & $\begin{array}{l}0.4047 \\
2.590\end{array}$ & $\begin{array}{l}\text { hectometer } \\
\text { square kilometer }\end{array}$ \\
\hline \multicolumn{3}{|c|}{$\underline{\text { Volume }}$} \\
\hline million gallons (Mgal) & 3,785 & cubic meter \\
\hline \multicolumn{3}{|c|}{ Flow } \\
\hline $\begin{array}{r}\text { gallon per minute } \\
\text { (gal/min) }\end{array}$ & 0.06309 & liter per second \\
\hline $\begin{array}{r}\text { million gallons per day } \\
(\mathrm{Mgal} / \mathrm{d})\end{array}$ & 0.04381 & cubic meter per second \\
\hline $\begin{array}{r}\text { inch per year (in/yr) } \\
\text { gallon per day per square mile } \\
(\mathrm{gal} / \mathrm{d}) / \mathrm{mi}^{2}\end{array}$ & $\begin{array}{l}25.4 \\
0.0146\end{array}$ & $\begin{array}{l}\text { millimeter per year } \\
\text { cubic meter per day per } \\
\text { square kilometer }\end{array}$ \\
\hline \multicolumn{3}{|c|}{ Transmissivity } \\
\hline $\begin{array}{r}\text { foot squared per day } \\
\left(\mathrm{ft}^{2} / \mathrm{d}\right)\end{array}$ & 0.0929 & meter squared per day \\
\hline \multicolumn{3}{|c|}{ Specific capacity } \\
\hline $\begin{array}{r}\text { gallon per minute per foot } \\
[(\mathrm{gal} / \mathrm{min}) / \mathrm{ft})]\end{array}$ & 0.207 & liter per second per meter \\
\hline
\end{tabular}

Equations for temperature conversion between degrees Celsius $\left({ }^{\circ} \mathrm{C}\right)$ and degrees Fahrenheit $\left({ }^{\circ} \mathrm{F}\right)$ :

$$
\begin{aligned}
{ }^{\circ} \mathrm{C} & =5 / 9\left({ }^{\circ} \mathrm{F}-32\right) \\
{ }^{\circ} \mathrm{F} & =\left(9 / 5^{\circ} \mathrm{C}\right)+32
\end{aligned}
$$

Sea level: In this report "sea level" refers to the National Geodetic Vertical Datum of 1929 (NGVD of 1929)--a geodetic datum derived from a general adjustment of the first-order level nets of the United States and Canada, formerly called Sea Level Datum of 1929.

Altitude, as used in this report, refers to distance above or below sea level.

Transmissivity: The standard unit for transmissivity is cubic foot per day per square foot times foot of aquifer thickness $\left[\left(\mathrm{ft}^{3} \mathrm{~d}\right) / \mathrm{ft}^{2}\right] \mathrm{ft}$.

\begin{tabular}{|c|c|}
\hline \multicolumn{2}{|c|}{$\underline{\text { Additional abbreviations }}$} \\
\hline $\begin{array}{r}\mu \mathrm{g} / \mathrm{L} \\
\mu \mathrm{S} / \mathrm{cm} \\
\mathrm{mg} / \mathrm{L}\end{array}$ & $\begin{array}{l}\text { micrograms per liter } \\
\text { microsiemens per centimeter at } 25 \text { degrees } C \\
\text { milligrams per liter }\end{array}$ \\
\hline \multicolumn{2}{|c|}{ Acronyms } \\
\hline FGS & Florida Geological Survey \\
\hline HRS & $\begin{array}{l}\text { Florida Department of Health and } \\
\text { Rehabilitative Services }\end{array}$ \\
\hline SJRWMD & St. Johns River Water Management District \\
\hline TU & Tritium units \\
\hline USGS & U.S. Geological Survey \\
\hline
\end{tabular}
In this report, the mathematically reduced form, foot squared per day $\left(\mathrm{ft}^{2} / \mathrm{d}\right)$, is used for convenience. 


\title{
Ground-Water Resources of Okeechobee County, Florida
}

\author{
by L.A. Bradner
}

\section{Abstract}

Rapid population growth in Okeechobee County, Florida, will probably increase demand for potable water. Use of ground water in the county during 1985 was estimated to be 24 million gallons per day. The surficial and Floridan aquifer systems are the sources of ground water used in the county.

Okeechobee County is poorly drained and much of the area is marshland. Although mean annual rainfall for the county ranges from 46 to 49 inches per year, most of the water leaves as evapotranspiration and, to a much lesser extent, as streamflow. Recharge to the Upper Floridan aquifer is less than 1 inch per year.

The surficial aquifer system is an important source of domestic and public water supply for the county because it contains potable water at shallow depths. The surficial aquifer system consists of undifferentiated sand, silt, and shell that is present as productive lenses of sand and shell between layers of silts and clays. Well yields range from 10 to 400 gallons per minute. The surficial aquifer system contains brackish water in some parts of the county. Three potential pathways by which brackish water can enter the surficial aquifer system are (1) upward leakage from the Floridan aquifer system, (2) infiltration from the land surface of water from free-flowing Floridan aquifer system wells, and (3) leakage through corroded Floridan aquifer system well casings. Water from the surficial aquifer system in places contains high concentrations of iron that can stain clothes and plumbing fixtures.
The Floridan aquifer system in Okeechobee County consists of the Tertiary-age Oldsmar Formation, the Avon Park Formation, the Ocala Limestone, and, where present, the Suwannee Limestone. The Floridan aquifer system is divided into two water-bearing units--the Upper and Lower Floridan aquifers. In most of the State, these two aquifers are separated by the denser middle semiconfining unit, but in Okeechobee County, the zone identified as this unit is as productive as the Upper Floridan aquifer (see section on Hydrogeology).

Yields from wells that tap the Upper Floridan aquifer typically range from 50 to 1,500 gallons per minute. Wells that tap the Lower Floridan aquifer yield as much as 6,500 gallons per minute. Use of the Floridan aquifer system for public water supply is limited in the southern part of the county because the water is marginally potable to brackish. The Floridan aquifer system is used extensively for agricultural irrigation throughout the county.

Chloride concentrations in water from the Floridan aquifer system generally increase with depth. Depth to brackish water ranges from 700 to more than 1,200 feet below land surface in the northern part of the county. The Floridan aquifer system in the southern part of the county (near the city of Okeechobee) and in the northeastern part of the county contains no freshwater. The lack of freshwater in these areas is caused by saltwater upconing as a result of large ground-water withdrawals, or through undocumented geologic faults. Wells in the Floridan aquifer system, which are completed in or near the lower Floridan aquifer 
or are far from recharge areas, typically yield brackish water. This is especially true in areas of large ground-water withdrawals.

Historical records indicate that the quality of water from the Floridan aquifer system has not changed significantly, except in the northeastern part of the county where brackish water may be moving upward. Chloride concentrations in water from wells that tap the Upper and Lower Floridan aquifers have been reduced through backplugging of the wells. Increased well development can further stress the surficial and Floridan aquifer systems and can result in additional upconing of brackish water at some pumping centers.

\section{INTRODUCTION}

The population of Okeechobee County (fig. 1) has increased about 200 percent from 11,000 in 1970 (Purdum and Anderson, 1988, p. 94) to 30,000 in 1990 (University of Florida, 1991). Almost 80 percent of the county's residents live in unincorporated areas, about 5,000 in the unincorporated city of Okeechobee. Continued population growth is likely to increase demand for potable water.

Ground water in Okeechobee County is used for domestic and public supply, and for agriculture. The county has no significant industrial or commercial water use. Ground-water use in 1985 was estimated to be about $24 \mathrm{Mgal} / \mathrm{d}$ (Marella, 1988).

The surficial aquifer system is used extensively for domestic and public supply and for agricultural use. The Floridan aquifer system is used extensively for agricultural irrigation and, to a lesser degree, for domestic and public supply. High-volume water use traditionally has been from the Floridan aquifer system.

The city of Okeechobee's main water-supply source is Lake Okeechobee. Recurring water-quality problems in the lake, such as algal blooms, affect the treatment methods and render poor-tasting water. Currently, the city's water supply is supplemented by ground water from the surficial aquifer system that is suitable for public supply after treatment.

The surficial aquifer system is the most accessible source of ground water because it is nearest the land surface. It contains freshwater in most areas. Contaminant spills as well as the application of poor- quality irrigation water from the Floridan aquifer system could, in some locations, degrade the quality of freshwater in the surficial aquifer system. The quality of water in the surficial aquifer system also can be affected by sources of contamination associated with urbanization, such as septic-tank effluent, stormwater runoff, and industrial and hazardous wastes.

Substantial withdrawals are made from the Floridan aquifer system for irrigation, livestock, and public supply. The Floridan aquifer system contains water that varies in salinity from fresh to brackish, generally in relation to depth within the aquifer. Saltwater is present in the aquifer system in some areas, particularly the northeastern and southern parts of Okeechobee County.

This study, the first countywide ground-water resource study undertaken in Okeechobee County, was conducted by the U.S. Geological Survey (USGS) in cooperation with the South Florida Water Management District. The study evaluates the water quality and water-supply potential in Okeechobee County in response to (1) increases in water demand for community water systems; (2) increases in water use from self-supplied rural areas which are undergoing development; (3) increases in agricultural irrigation resulting from an increase in irrigated-crop acreage; and (4) potential need for water for new industries.

Brackish water is typically defined as water having a dissolved-solids concentration between 1,000 and $10,000 \mathrm{mg} / \mathrm{L}$ (Schiner and others, 1988). In this report, however, brackish water is defined as water having a chloride concentration between 250 and $5,000 \mathrm{mg} / \mathrm{L}$. This definition is used because the recommended limit for chloride concentration in water for public supply is $250 \mathrm{mg} / \mathrm{L}$ (Florida Department of State, 1989). Also, with larger withdrawals, wells that tap the Floridan aquifer system and yield water having a chloride concentration greater than $250 \mathrm{mg} / \mathrm{L}$ generally tend to yield water that increases in chloride concentration as withdrawals increase.

\section{Purpose and Scope}

This report describes the hydrogeologic framework and hydraulic properties of the aquifer systems in Okeechobee County, discusses the quality of the ground water and the direction of ground-water flow, and identifies long-term trends in water levels and water quality within the aquifer systems. 


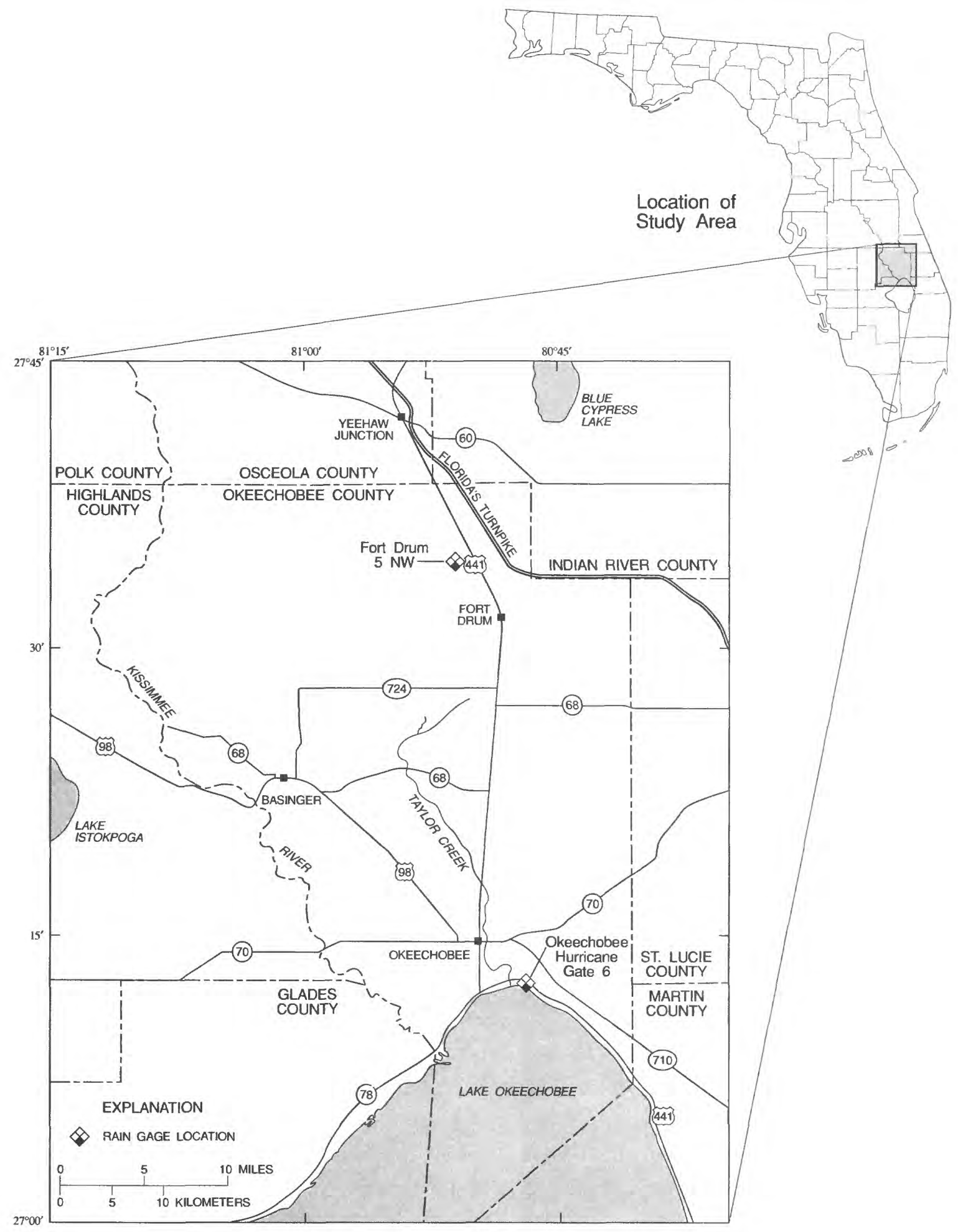

Figure 1. Location of study area and rainfall-gaging stations. 
Data for this report are from publications and files of the USGS, the Florida Geological Survey (FGS), the South Florida Water Management District (SFWMD), the Florida Department of Health and Rehabilitative Services (HRS), and reports prepared by private consultants and oil companies. Additional data collected by USGS and SFWMD personnel from 1989 through 1991 were used to supplement the previously available information.

Information on the hydrogeologic framework and hydraulic properties was compiled from lithologic well $\log$, geophysical well $\operatorname{logs}$, aquifer test data and potentiometric surface maps from the above sources. Ground-water quality was described from results of previous and current water-quality analyses of groundwater samples collected and analyzed by USGS and the SFWMD personnel, and from statistical data generated by the USGS from results of water-quality analyses obtained from HRS.

\section{Previous Studies}

Generalized geohydrologic information on Okeechobee County is presented in several reports by the SFWMD on the Kissimmee Planning Area (Reese and others, 1984; Shaw and Trost, 1984a, 1984b). Detailed geologic structure contours and accompanying information were published for Okeechobee County and the adjacent counties of St. Lucie and Martin by Hydrodesigns, Inc., a consulting firm, for the SFWMD (Hydrodesigns, Inc., 1988). Reports by the USGS on the geology and water resources of the area include those by Stringfield (1936), Parker and others (1955), Miller (1986), Meyer (1989), and Tibbals (1990). Transmissivities and recharge rates to the Floridan aquifer system in east-central Florida were investigated by Tibbals (1990) and used in a digital ground-waterflow model. Potentiometric-surface maps of the Upper Floridan aquifer for annual high (September) and low (May) water levels are available for most years since 1973 (on file at the Altamonte Springs office of the U.S. Geological Survey).

\section{Well-Numbering Systems}

A 15-digit number based on latitude and longitude is used to identify wells in the USGS data storage and retrieval systems. The first 6 digits denote the degrees, minutes, and seconds of latitude; the next
7 digits denote degrees (always 3 digits beginning with 0 ), minutes, and seconds of longitude; and the last 2 digits denote a sequential number for a well within a 1 -second grid. Well reference numbers listed in table 1 and shown in figure 5 denote wells used in this report and are different from local well numbers previously used by the USGS and the SFWMD.

\section{Acknowledgments}

The author thanks the Hydrogeology Section of the SFWMD and Mike Knapp, previously of Hydrodesigns, Inc., for their assistance in acquiring geologic information. The author also acknowledges the landowners who allowed access to their property during the study. Cooperation of the employees of the City of Okeechobee Water Department, American Water Systems Well Drilling, Domers Well Drilling, and the St. Johns River Water Management District is greatly appreciated.

\section{DESCRIPTION OF THE STUDY AREA}

Okeechobee County consists of $770 \mathrm{mi}^{2}$ of land and $121 \mathrm{mi}^{2}$ of water in south-central Florida (fig. 1). The county is bounded on the east by Indian River, Martin, and St. Lucie Counties, on the north by Osceola County, and on the west by Highlands and Glades Counties. The extreme southern part of the county includes a pie-shaped area of Lake Okeechobee. Most of the population is concentrated in and around the city of Okeechobee, located in the southern part of the county. The major employers are agriculture, tourism, and government.

\section{Physiography and Drainage}

Land-surface altitude within Okeechobee County ranges from about 10 to $75 \mathrm{ft}$. Altitudes generally are higher in the northern part of the county than in the southern part.

The topography has been largely influenced by the formation of five marine terraces during the Pleistocene Epoch (Parker and others, 1955). These marine terraces are flat, horizontal expanses of sand and shell deposits that were once the sea floor, when sea level was higher than at present. The five terraces in Okeechobee County are, from highest to lowest: (1) the Wicomico Terrace, (2) the Penholoway Terrace, 
(3) the Talbot Terrace, (4) the Pamlico Terrace, and

(5) the Silver Bluff Terrace (fig. 2). These terraces are mapped by altitude above present sea level.

The Wicomico Terrace, the highest of the terraces, is in the northern part of the county. The lower limit of this terrace is about $70 \mathrm{ft}$ above sea level. The Penholoway Terrace covers a significant part of the county; its lower limit is about $42 \mathrm{ft}$ above sea level. The relict shoreline of the Talbot Terrace is well developed and the land surface declines steeply along the contact with the Penholoway Terrace. The Talbot Terrace is defined by land-surface altitudes ranging from 25 to $42 \mathrm{ft}$. The Pamlico and Silver Bluff Terraces are shown as a single land mass below the 25 - $\mathrm{ft}$ altitude because of the difficulty in determining their relict shorelines. The Pamlico and Silver Bluff terraces are in the southern part of the county along Lake Okeechobee and at the northeastern corner of the county.

Surface-water drainage in Okeechobee County is controlled largely by the topography of the Penholoway Terrace. The county is poorly drained and much of the area is marshland. Many farming and grazing areas are drained by ditches, canals, and shallow swales. Natural drainage occurs within the four major drainage basins: (1) the Kissimmee River, (2) Taylor Creek and Upper Okeechobee, (3) the Upper St. Johns River, and (4) the St. Lucie- Martin County (draining to Lake Okeechobee) basins (fig. 2).

\section{Climate}

The climate of the study area is characterized as subtropical humid with high annual rainfall and moderate temperatures. The average air temperature is about $74^{\circ} \mathrm{F}$.

In most years, about 65 percent of the average annual rainfall occurs during June through October. Local thunderstorms account for most summer rainfall that is usually unevenly distributed throughout the study area. Normal summer rainfall can be substantially augmented by occasional tropical storms and hurricanes that may pass over or near the Florida peninsula. Winter rains tend to be regional in distribution and are associated with large, frontal-type weather systems.

Long-term rainfall data are available for two stations in Okeechobee County--the Fort Drum 5 NW and Okeechobee Hurricane Gate 6 stations (fig. 1).
Mean annual rainfall at the Fort Drum 5 NW station for 1957-90 is about 49 in. (fig. 3) (excluding 2 years for which data are unavailable). Mean annual rainfall at the Okeechobee Hurricane Gate 6 for 1948-90 is about 46 in. (excluding 6 nonconsecutive years for which data are unavailable). Evapotranspiration is a major component of the hydrologic budget in Okeechobee County. Quantification of evapotranspiration is difficult but the upper limit of annual evapotranspiration rates can be estimated. The upper limit of evapotranspiration is about equal to the rate at which water can evaporate from a free-water surface (such as a lake) under natural conditions. The maximum potential evaporation ranges from 48 to $50 \mathrm{in} / \mathrm{yr}$ in Okeechobee County (Visher and Hughes, 1975).

Evapotranspiration rates for the county generally depend on the depth to the water table, which ranges from land surface to about $5 \mathrm{ft}$ below land surface. Based on an estimated relation between depth to water and evapotranspiration developed by Tibbals (1978), evapotranspiration rates in the county are estimated to range from 35 to $48 \mathrm{in} / \mathrm{yr}$. Evapotranspiration rates probably are near the high end of this range in much of the county because of the widespread marshy conditions.

\section{Land Use}

Land use in the county is predominantly agricultural and includes dairies, pastures, sod and truck farms, and citrus groves. The city of Okeechobee is mostly commercial and residential. Small areas of the county are industrial, whereas large areas are undeveloped because they are wet or marshy.

\section{Hydrogeology}

The study area is underlain mostly by layers of sand, shell, clay, limestone, dolomite, gypsum, anhydrite, and shale, which together range in thickness from about 8,000 to $12,000 \mathrm{ft}$ (Schiner and others, 1988). In this report, discussion is limited to a brief description of the hydrogeologic framework and related geologic units. This includes hydraulically important formations at depths to about $2,500 \mathrm{ft}$. Figure 4 describes the hydrogeologic and geologic units and their relation to the ground-water flow system in Okeechobee County. 


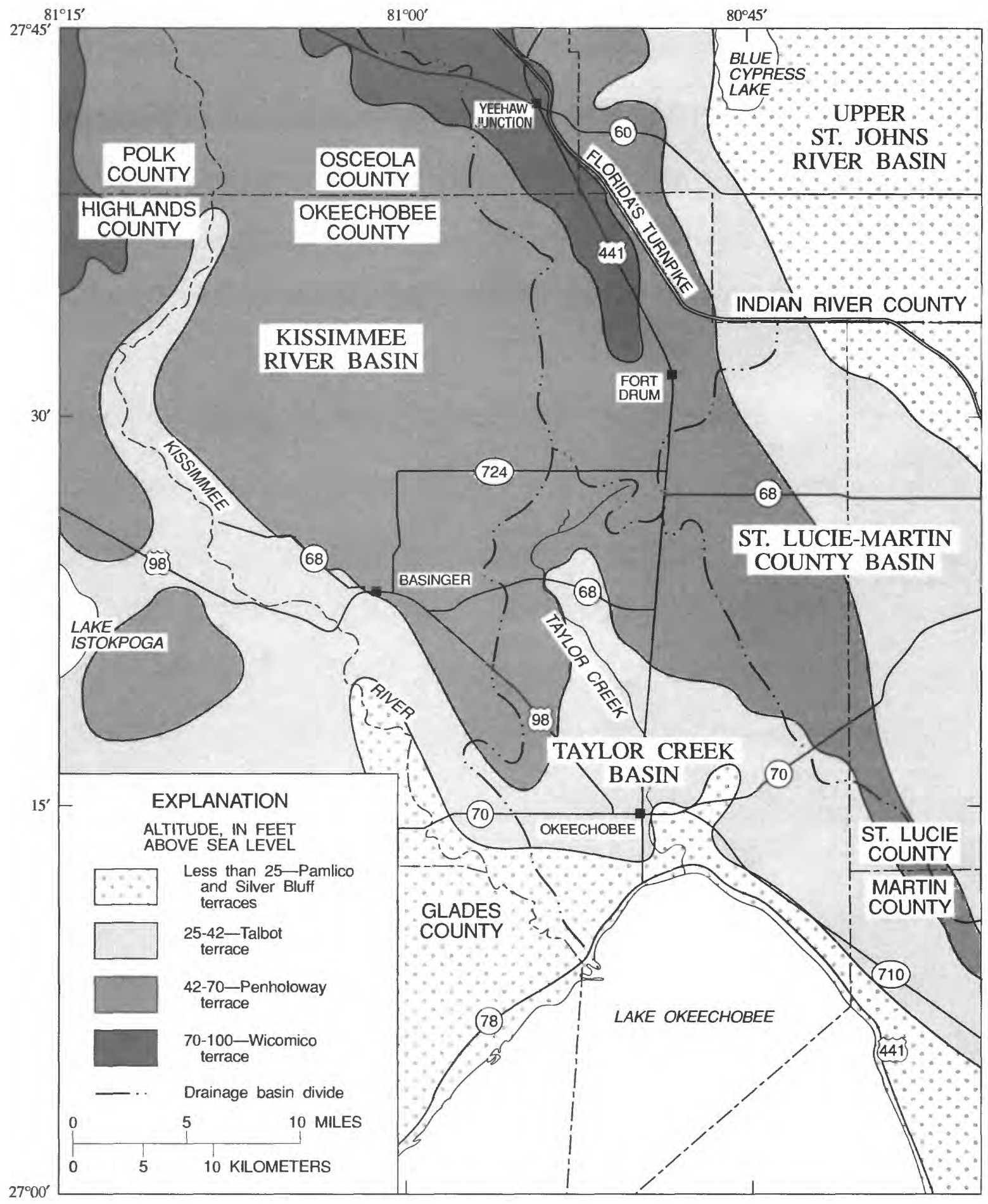

Figure 2. Pleistocene marine terraces in the study area (modified from Parker and others, 1955, pl. 10). 
The hydrogeologic units discussed in this report are the surficial aquifer system, the intermediate confining unit, the Floridan aquifer system, and the sub-Floridan confining unit. The surficial aquifer system, consisting of the undifferentiated deposits of the Holocene, Pleistocene, Pliocene, and Late Miocene, is separated from the Floridan aquifer system by earlier Miocene sands, silts, and clays of the Hawthorn Formation, referred to as the intermediate confining unit.

The Floridan aquifer system is divided into two major water-bearing units--the Upper and Lower Floridan aquifers. In this report, the terminology relating to the aquifers is slightly modified from that described by Tibbals (1990). The middle semiconfining unit of the Floridan aquifer system was determined to have a permeability equal to or greater than that of the upper part of the Floridan aquifer system in Okeechobee County; thus, the middle semiconfining unit is considered to be a water-bearing zone within the Upper Floridan aquifer in the study area. The Upper Floridan aquifer contains the Suwannee Limestone (where present), Ocala Limestone, and the upper part of the Avon Park Formation. The Lower Floridan aquifer consists of the lower part of the Avon Park Formation and the Oldsmar Formation.

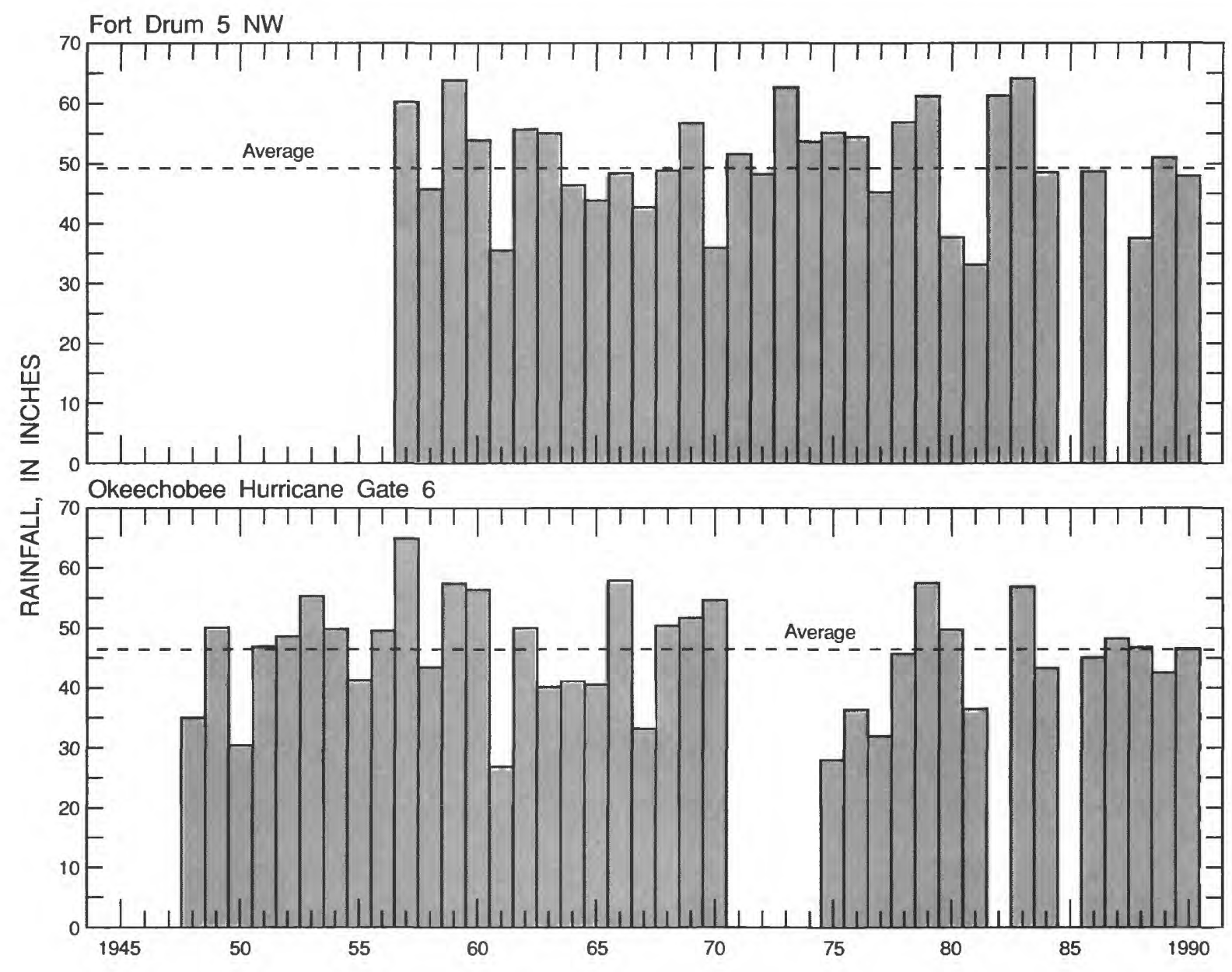

Figure 3. Annual rainfall at Fort Drum 5 NW, 1957-90, and at Okeechobee Hurricane Gate 6, 1948-90. 
The Oldsmar Formation is of early Eocene age and is the deepest and oldest part of the Floridan aquifer system in Okeechobee County (Tibbals, 1990). It consists of dolomite and limestone and its top is about 1,500 ft below land surface in Okeechobee County. Water wells in the county do not tap this formation because it contains water that is too salty for most uses.

The oldest geologic unit penetrated by water wells in Okeechobee County is the Avon Park Formation of middle Eocene age. This formation is composed of white to brown limestone and dolomite beds, and is characterized by dense, indurated zones that tend to alternate with more porous zones. The top of the Avon Park Formation generally dips south to southeast in Okeechobee County and ranges from $450 \mathrm{ft}$ below land surface in the northern part of the county to more than $700 \mathrm{ft}$ below land surface in the southeastern part of the county.
The Ocala Limestone overlies the Avon Park Formation throughout the study area. The Ocala, of late Eocene age, is a white to tan, highly fossiliferous limestone that ranges in thickness from 100 to $300 \mathrm{ft}$. Most wells that tap the Floridan aquifer system are open to both the Ocala Limestone and the Avon Park Formation.

The Suwannee Limestone, also of late Eocene age, is a hard, gray limestone layer that is absent in most of the county. Where present, it appears as a hard caprock overlying the Ocala Limestone and usually is less than $5 \mathrm{ft}$ thick.

The early-to-middle Miocene Hawthorn Formation (the intermediate confining unit) overlies the Ocala Limestone or Suwannee Limestone (where present). The formation consists of sandy clay and marl, interbedded with lenses of phosphorite pebbles, phosphatic sand, and phosphatic sandy limestone.

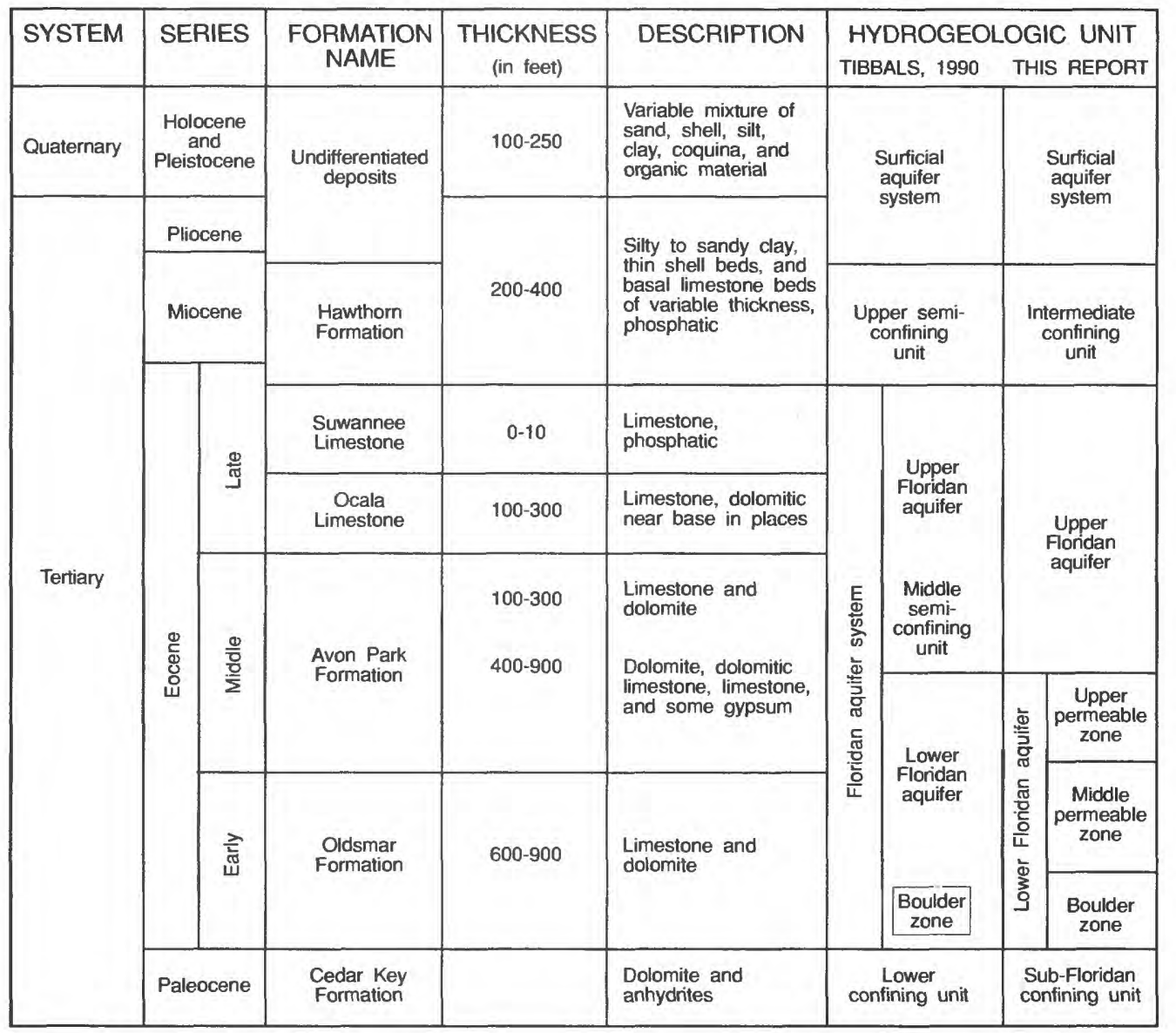

Figure 4. Description of the hydrogeologic and geologic units in Okeechobee County, Fla. 
Late Miocene or Pliocene deposits overlie the Hawthorn Formation. These deposits generally consist of clayey sand and silt layers with lenses of medium to coarse sand and shell. In some areas of the county, these lenses also contain loosely consolidated limestone.

The surficial sediments consist of undifferentiated sand, clay, silt, and shell deposits of Pleistocene and Holocene age. The sands and shells are interlayered with thin layers of clay, silt and fine sand. Some shell layers are about $50 \mathrm{ft}$ thick and some have been mined for roadbed material.

Wells used to obtain the water-level, waterquality, and geologic information in this report are listed in table 1 and their locations are shown in figure 5. Locations of geologic and hydrogeologic sections through the study area are shown in figure 5; figures 6 and 7 show the four hydrogeologic sections extending north to south and west to east. The hydrogeologic sections indicate that the undifferentiated surficial deposits are of relatively uniform thickness throughout the county, whereas the intermediate confining unit increases in thickness from about $200 \mathrm{ft}$ in the northern and northwestern parts of the county to more than $400 \mathrm{ft}$ in the southern and southeastern parts of the county.

\section{GROUND-WATER RESOURCES}

The ground water used in Okeechobee County is withdrawn from two aquifer systems, the surficial and the Floridan aquifer systems. Both aquifer systems are multilayered and are variable in physical and chemical properties.

\section{Surficial Aquifer System}

The surficial aquifer system is the most widely used source of drinking water in Okeechobee County. In most parts of the county, the aquifer system contains freshwater that is easily obtainable for low-cost domestic supply.

\section{Hydrogeologic Framework}

The surficial aquifer system within Okeechobee County consists of undifferentiated sediments that overlie the greenish-gray clayey sands of the intermediate confining unit (Hawthorn Formation). The surficial aquifer system consists of a relatively thin unit of undifferentiated sand, silt, and shell of Pleistocene to Holocene age overlying more permeable zones composed of thin layers of sand, silt, and clay interbedded with layers of limestone, coarse sand, and shell of Pliocene age. In some places, the permeable beds are absent and wells are drilled into the deeper sand, shell, and silt layers of Late Miocene age. These deeper wells also are classified as surficial aquifer system wells.

A gamma-ray $\log$ and lithologic description of the top $250 \mathrm{ft}$ in well 23 indicate that the layers penerated by the well are highly variable in composition and thickness (fig. 8). The surficial aquifer system at this well is about $240 \mathrm{ft}$ thick. The thickness of the surficial aquifer system in Okeechobee County increases southward from about 150 to more than $250 \mathrm{ft}$ (fig. 9) but is generally between 200 and $250 \mathrm{ft}$.

\section{Description of Wells}

Well-completion reports examined at the SFWMD indicate that domestic and irrigation wells that tap the surficial aquifer system in the county probably number more than 1,000 . Selected wells were inventoried during this study for data acquisition. Well depths generally are in one of three ranges. Wells that penetrate the surficial sands generally range between 30 and $60 \mathrm{ft}$ in depth and have slotted screen in the bottom $10 \mathrm{ft}$ of the well. Wells that penetrate the middle permeable zone generally range between 100 and $140 \mathrm{ft}$ in depth and have slotted screen or open hole in the bottom $40 \mathrm{ft}$ of the well. Wells that tap the lower zones of the surficial aquifer system generally range between 180 and $240 \mathrm{ft}$ in depth and have slotted screen or open hole in the bottom 40 to $60 \mathrm{ft}$ of the well.

\section{Water Table}

The water table in the surficial aquifer system in Okeechobee County ranges from land surface to about $10 \mathrm{ft}$ below land surface and fluctuates in response to seasonal changes in precipitation, pumping, and evapotranspiration. The water table can also fluctuate in response to regulation of flows in the county's surface-drainage network. Annual fluctuations in the water table average about $4 \mathrm{ft}$. 
Table 1. Wells in the study area used to obtain water-level, water-quality, and geologic data

[Type of data collected--QW, water quality; WL, water level; L, lithologic; G, geophysical logs. Aquifer codes: S, surficial aquifer sytem; H, Intermediate confining unit; U, Upper Floridan aquifer, L, Lower Floridan aquifer, ?, aquifers estimated; --, missing data]

\begin{tabular}{|c|c|c|c|c|c|}
\hline $\begin{array}{l}\text { Well } \\
\text { reference } \\
\text { number }\end{array}$ & Site number & $\begin{array}{c}\text { Altitude } \\
\text { of } \\
\text { land surface } \\
\end{array}$ & $\begin{array}{l}\text { Type of } \\
\text { data } \\
\text { collected }\end{array}$ & $\begin{array}{l}\text { hell depth } \\
\text { (feet) }\end{array}$ & $\begin{array}{l}\text { Aquifer } \\
\text { penetrated }\end{array}$ \\
\hline $\begin{array}{l}\text { C.PDCAODB } \\
1 \\
2 \\
3 \\
4 \\
5\end{array}$ & $\begin{array}{l}\frac{\text { PE CONIII }}{270755080413701} \\
271110080414501 \\
271139080534301 \\
271140080452001 \\
271327080560401\end{array}$ & $\begin{array}{l}15 \\
34.67 \\
18 \\
17 \\
24\end{array}$ & $\begin{array}{l}L \\
Q W, W L \\
Q W, L \\
Q W \\
Q H\end{array}$ & $\begin{array}{l}1,008 \\
433 \text { (CASING BLOCKED) } \\
1,313 \\
625 \text { (PLUGGED) } \\
\text { UNKNOWN }\end{array}$ & $\begin{array}{l}\mathrm{U} \\
\mathrm{B}, \mathrm{U}, \mathrm{L} \text { ? } \\
\mathrm{B}, \mathrm{U}, \mathrm{L} \\
\mathrm{U}, \mathrm{L} \text { ? } \\
\mathrm{U}, \mathrm{L} \text { ? }\end{array}$ \\
\hline $\begin{array}{r}6 \\
7 \\
8 \\
9 \\
10\end{array}$ & $\begin{array}{l}271337080574501 \\
271340080444001 \\
271340080504001 \\
271357080542801 \\
271401080561001\end{array}$ & $\begin{array}{l}22 \\
31.81 \\
24.22 \\
28 \\
25\end{array}$ & $\begin{array}{l}Q W \\
Q W, W L, I \\
Q W, W L, L \\
Q W, G \\
Q W, W L\end{array}$ & $\begin{array}{l}60 \\
1,448 \\
1,079 \\
1,260 \text { (PLUGGED) } \\
1,100\end{array}$ & $\begin{array}{l}\text { S } \\
\text { B, U, L } \\
\text { B, U, L } \\
\text { B, U, L } \\
\text { U? ? }\end{array}$ \\
\hline $\begin{array}{l}11 \\
12 \\
13 \\
14 \\
15\end{array}$ & $\begin{array}{l}271411080461201 \\
271420080471201 \\
271429080581801 \\
271430080574301 \\
271436080492401\end{array}$ & $\begin{array}{l}28.66 \\
25 \\
27 \\
33 \\
20\end{array}$ & $\begin{array}{l}Q W, W L \\
Q W, W L, G, L \\
Q H, L \\
Q H \\
L\end{array}$ & $\begin{array}{l}550 \text { (CASING BLOCKED) } \\
1,700 \text { IEST WELL } \\
1,110 \\
1,250 \\
1,175\end{array}$ & $\begin{array}{l}\text { 日, U, L ? } \\
\text { L } \\
U \\
U \\
\text { B, U, L }\end{array}$ \\
\hline $\begin{array}{l}16 \\
17 \\
18 \\
19 \\
20\end{array}$ & $\begin{array}{l}271438080523201 \\
271438080571901 \\
271439080565301 \\
271446080501601 \\
271451080450801\end{array}$ & $\begin{array}{l}33 \\
32.89 \\
32.72 \\
30 \\
32\end{array}$ & $\begin{array}{l}Q W \\
Q W \\
Q W, W L \\
I \\
Q W\end{array}$ & $\begin{array}{l}1.425 \\
\text { UNRONOWN } \\
700 \\
718 \\
\text { UNKONOWN }\end{array}$ & $\begin{array}{l}\mathrm{U}, \mathrm{L} \\
\mathrm{U} \\
\mathrm{U} \\
\mathrm{U} \\
\mathrm{U}, \mathrm{L}\end{array}$ \\
\hline $\begin{array}{l}21 \\
22 \\
23 \\
24 \\
25\end{array}$ & $\begin{array}{l}271456080500701 \\
271514080511601 \\
271526080490101 \\
271552080564201 \\
271610080533001\end{array}$ & $\begin{array}{l}29.73 \\
34.44 \\
22 \\
35.11 \\
32\end{array}$ & $\begin{array}{l}Q H, W L \\
Q H, W L, L \\
Q H, W L, G, L \\
Q H, W L \\
Q H\end{array}$ & $\begin{array}{r}1.327 \\
925 \\
840 \\
1.100 \\
\text { Uningowin }\end{array}$ & 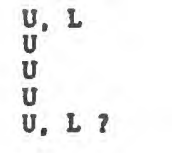 \\
\hline $\begin{array}{l}26 \\
27 \\
28 \\
29 \\
30\end{array}$ & $\begin{array}{l}271640080571501 \\
271821080531801 \\
271830080493501 \\
271830080493502 \\
271830080493504\end{array}$ & $\begin{array}{l}35.12 \\
37 \\
33.84 \\
33.94 \\
34\end{array}$ & $\begin{array}{l}\text { QH,WL } \\
\text { OH,G } \\
\text { QH,L } \\
L \\
\text { QW }\end{array}$ & $\begin{array}{r}1,100 \\
1,300 \\
725 \\
825 \\
230\end{array}$ & $\begin{array}{l}\mathrm{U} \\
\mathrm{U}, \mathrm{U}, \mathrm{L} \\
\mathrm{U} \\
\mathrm{U} \\
\mathrm{S}\end{array}$ \\
\hline $\begin{array}{l}31 \\
32 \\
33 \\
34 \\
35\end{array}$ & $\begin{array}{l}271835080440101 \\
271855080482501 \\
271900080482001 \\
27193408059130 \\
271947080585301\end{array}$ & $\begin{array}{l}60 \\
31.72 \\
30 \\
35.22 \\
35\end{array}$ & $\begin{array}{l}\text { QH,WL, G } \\
\text { QH,WL, G } \\
\text { QH,WL } \\
\text { QH,WL } \\
\text { QH,L }\end{array}$ & $\begin{array}{l}922 \\
1,098 \text { (BACKPLUGGED FROM 1173) } \\
1,910 \\
1,305 \\
1,125\end{array}$ & $\begin{array}{ll}\text { B, } & \text { U } \\
U & \\
U, & L \\
U, & L \\
U & L\end{array}$ \\
\hline $\begin{array}{l}36 \\
37 \\
38 \\
39 \\
40\end{array}$ & $\begin{array}{l}272010080550801 \\
272158080470901 \\
272227080572901 \\
272235080573001 \\
272315081010901\end{array}$ & $\begin{array}{l}41.54 \\
61.98 \\
56 \\
42 \\
47\end{array}$ & $\begin{array}{l}\text { QH,WL, G } \\
Q W, W L, G \\
L \\
\text { QW } \\
\text { WL }\end{array}$ & $\begin{array}{r}586 \\
963 \\
10,836 \\
1,100 \\
21\end{array}$ PLUGGED OIL WELL & $\begin{array}{l}U \\
U \\
U, L \\
S\end{array}$ \\
\hline $\begin{array}{l}41 \\
42 \\
43 \\
44 \\
45\end{array}$ & $\begin{array}{l}272318080561901 \\
272318081423401 \\
272321080415901 \\
272335080533101 \\
272344080550701\end{array}$ & $\begin{array}{l}43.96 \\
60 \\
41 \\
35 \\
45\end{array}$ & $\begin{array}{l}Q H, W L, G \\
L \\
Q W \\
Q H, L \\
Q W\end{array}$ & $\begin{array}{l}11,277 \text { PLUGGED OIL WELL } \\
\text { UNKWOWN } \\
1,030 \\
60\end{array}$ & $\begin{array}{l}\text { U } \\
\text { U. L ? } \\
\text { U, L } \\
\text { S }\end{array}$ \\
\hline $\begin{array}{l}46 \\
47 \\
48 \\
49 \\
50\end{array}$ & $\begin{array}{l}272403081065801 \\
272430081035501 \\
272445080554101 \\
272448080505901 \\
272512080574701\end{array}$ & $\begin{array}{l}35 \\
50 \\
46 \\
60 \\
50\end{array}$ & $\begin{array}{l}\text { QH,WL,L } \\
\text { QH,WL } \\
\text { QH,WL, G } \\
L \\
\text { QH,L }\end{array}$ & $\begin{array}{r}1,100 \\
1,900 \\
972 \\
740 \\
1,156\end{array}$ & $\begin{array}{l}U \\
U \\
U \\
U \\
U\end{array}$ \\
\hline $\begin{array}{l}51 \\
52 \\
53 \\
54 \\
55\end{array}$ & $\begin{array}{l}272512081014001 \\
272542080500801 \\
272600081051001 \\
272630080503001 \\
272656080440701\end{array}$ & $\begin{array}{l}47.49 \\
70 \\
52 \\
70 \\
40\end{array}$ & $\begin{array}{l}Q H, W L \\
L \\
L, G \\
L, G \\
Q H\end{array}$ & $\begin{array}{r}1.100 \\
800 \\
8,185 \\
1.039 \\
120\end{array}$ & $\begin{array}{l}\text { U } \\
\text { U } \\
\text { B, U } \\
\text { S }\end{array}$ \\
\hline $\begin{array}{l}56 \\
57 \\
58 \\
59 \\
60\end{array}$ & $\begin{array}{l}272656080440801 \\
272701080575501 \\
272704081053501 \\
272726081003901 \\
272810080520001\end{array}$ & $\begin{array}{l}40 \\
65.36 \\
54.70 \\
56.92 \\
66\end{array}$ & $\begin{array}{l}\text { QH } \\
\text { QH,WL,G } \\
\text { QH,WL } \\
\text { QH,WL, G } \\
\text { QH,L }\end{array}$ & $\begin{array}{l}600 \\
948 \\
\text { UnTNOWN } \\
1,015 \\
1,400\end{array}$ & $\begin{array}{l}\mathrm{B}, \mathrm{U} \\
\mathrm{U} \\
\mathrm{U} \\
\mathrm{U} \\
\mathrm{U}, \mathrm{I}\end{array}$ \\
\hline
\end{tabular}


Table 1. Wells in the study area used to obtain water-level, water-quality, and geologic data--Continued

[Type of data collected--QW, water quality; WL, water level; L, lithologic; G, geophysical logs. Aquifer codes: S, surficial aquifer sytem; H, Intermediate confining unit; U, Upper Floridan aquifer; L, Lower Floridan aquifer; ?, aquifers estimated; --, missing data]

\begin{tabular}{|c|c|c|c|c|c|}
\hline $\begin{array}{l}\text { Well } \\
\text { reference } \\
\text { number }\end{array}$ & Site number & $\begin{array}{c}\text { Altitude } \\
\text { of } \\
\text { land surface }\end{array}$ & $\begin{array}{c}\text { Type of } \\
\text { deta } \\
\text { collected }\end{array}$ & $\begin{array}{l}\text { Hell depth } \\
\text { (feet) }\end{array}$ & $\begin{array}{c}\text { Aquifer } \\
\text { penetrated }\end{array}$ \\
\hline \multicolumn{6}{|c|}{ 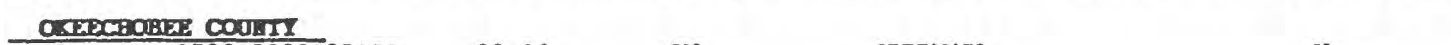 } \\
\hline 61 & 272815080425401 & 33.16 & $\alpha+$ & UNONOWN & $\mathbf{u}$ \\
\hline 62 & 272820080595701 & 60 & $\alpha_{H}$ & UNXorowis & U? \\
\hline $\begin{array}{l}63 \\
64\end{array}$ & $\begin{array}{l}272833080455301 \\
27285080595801\end{array}$ & 54.68 & $\alpha H$ & 1,110 & U \\
\hline $\begin{array}{l}64 \\
65\end{array}$ & 272934080515801 & 67.68 & $\begin{array}{l}Q W, W L, G \\
Q W, L\end{array}$ & $\begin{array}{l}1,039 \\
1,200\end{array}$ & U, L \\
\hline 66 & 273011081075201 & 55 & $Q W, W L, L, G$ & 780 & в. U \\
\hline 67 & 273035080564001 & 70 & & 400 & U. \\
\hline $\begin{array}{l}68 \\
69\end{array}$ & 273043080440001 & 33.27 & QH & UNKNOWN & U. L ? \\
\hline 70 & $\begin{array}{l}273103080414501 \\
273114080533601\end{array}$ & $\begin{array}{l}28 \\
70\end{array}$ & $\begin{array}{l}\text { OH,G } \\
\text { WL. }\end{array}$ & $\begin{array}{r}720 \\
1,200\end{array}$ & $\underset{U}{U}$ \\
\hline 71 & 273124081012401 & 65.55 & QW, HL & 896 & $\mathbf{u}$ \\
\hline 72 & 273127080481401 & 54 & & 960 & u \\
\hline 73 & 273148080561301 & 69 & & 775 & U \\
\hline $\begin{array}{l}74 \\
75\end{array}$ & $\begin{array}{l}273156080522101 \\
273217081012601\end{array}$ & $\begin{array}{l}69 \\
67.01\end{array}$ & $\begin{array}{l}\text { QH,G } \\
Q W, W L\end{array}$ & $\begin{array}{l}718 \\
\text { UNXNOWN }\end{array}$ & $\begin{array}{l}\text { U } \\
\text { U ? }\end{array}$ \\
\hline 76 & 273238080421401 & 28.07 & QW, WL. & 686 & $\mathrm{u}$ \\
\hline 77 & 273238080424201 & 28.74 & QH.G & 686 & ư \\
\hline $\begin{array}{l}78 \\
79\end{array}$ & 273300080493901 & & $Q \mathrm{H}_{2} \mathrm{~L}$ & 840 & ปี \\
\hline $\begin{array}{l}79 \\
80\end{array}$ & $\begin{array}{l}273331080493101 \\
273451080514801\end{array}$ & $\begin{array}{l}66 \\
71\end{array}$ & $\begin{array}{l}L, G \\
G\end{array}$ & $\begin{array}{l}740 \\
984\end{array}$ & $\begin{array}{l}0 \\
u\end{array}$ \\
\hline 81 & 273602080492301 & 55 & $Q H, G, L$ & 530 & $\mathbf{u}$ \\
\hline 82 & 273616080470501 & & $Q W, G$ & 912 & U, $L$ \\
\hline 83 & 273740080551201 & 65.43 & QW,WL,G & 573 & U. $\bar{L}$ \\
\hline \multicolumn{6}{|c|}{ GLADES COOHIR } \\
\hline 84 & 270848080552401 & 17 & G.QW & 824 & B,U \\
\hline \\
\hline $\begin{array}{l}85 \\
86\end{array}$ & 271731081043901 & 41 & $\mathrm{~L}$ & 1,310 & U \\
\hline \multicolumn{5}{|c|}{ MARTII COOATR } & \\
\hline$\frac{\text { MARTLC }}{87}$ & $\frac{00.11}{270558080392701}$ & -- & L & 992 & $\mathbf{u}$ \\
\hline \multicolumn{6}{|c|}{ OSCRDOLA COUIIII } \\
\hline 88 & 273952080580601 & -- & L & -- & -- \\
\hline 89 & 274035081080201 & -- & L & -- & -- \\
\hline 90 & 274145081063501 & -- & $\overline{\mathbf{L}}$ & -- & -- \\
\hline \multicolumn{6}{|c|}{ ST, LUCIE COUITI } \\
\hline $\begin{array}{l}91 \\
92\end{array}$ & $\begin{array}{l}271540080363001 \\
272604080404001\end{array}$ & $\overline{-}$ & $\frac{1}{2}$ & $\begin{array}{r}1,300 \\
867\end{array}$ & B, U, I \\
\hline \multicolumn{6}{|c|}{$\frac{\text { COVIIII }}{273929081080601}$} \\
\hline & 273929081080601 & 60 & I,G & 1.000 & $\mathbf{u}$ \\
\hline
\end{tabular}




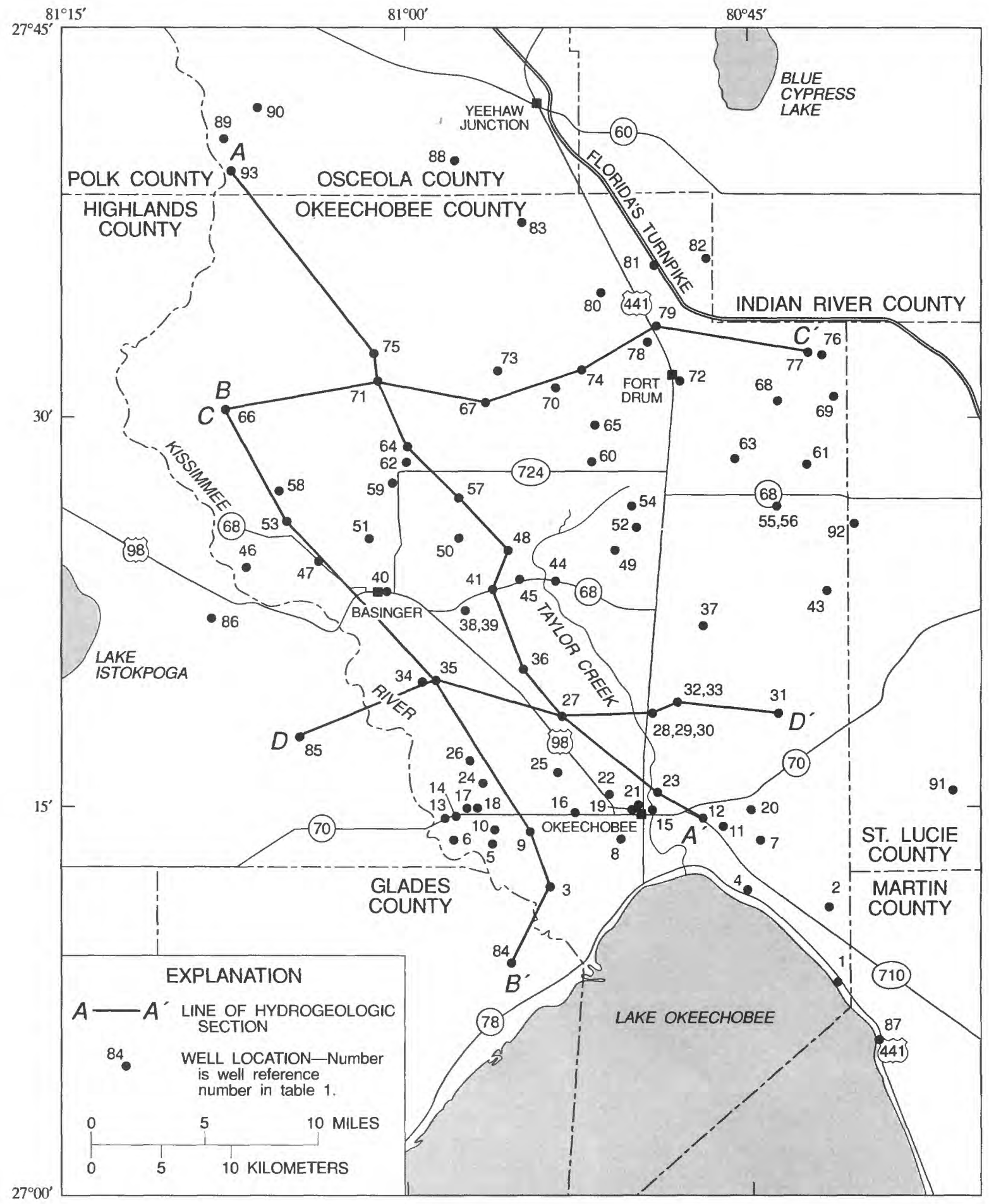

Figure 5. Locations of wells used for data collection and lines of hydrogeologic section. 

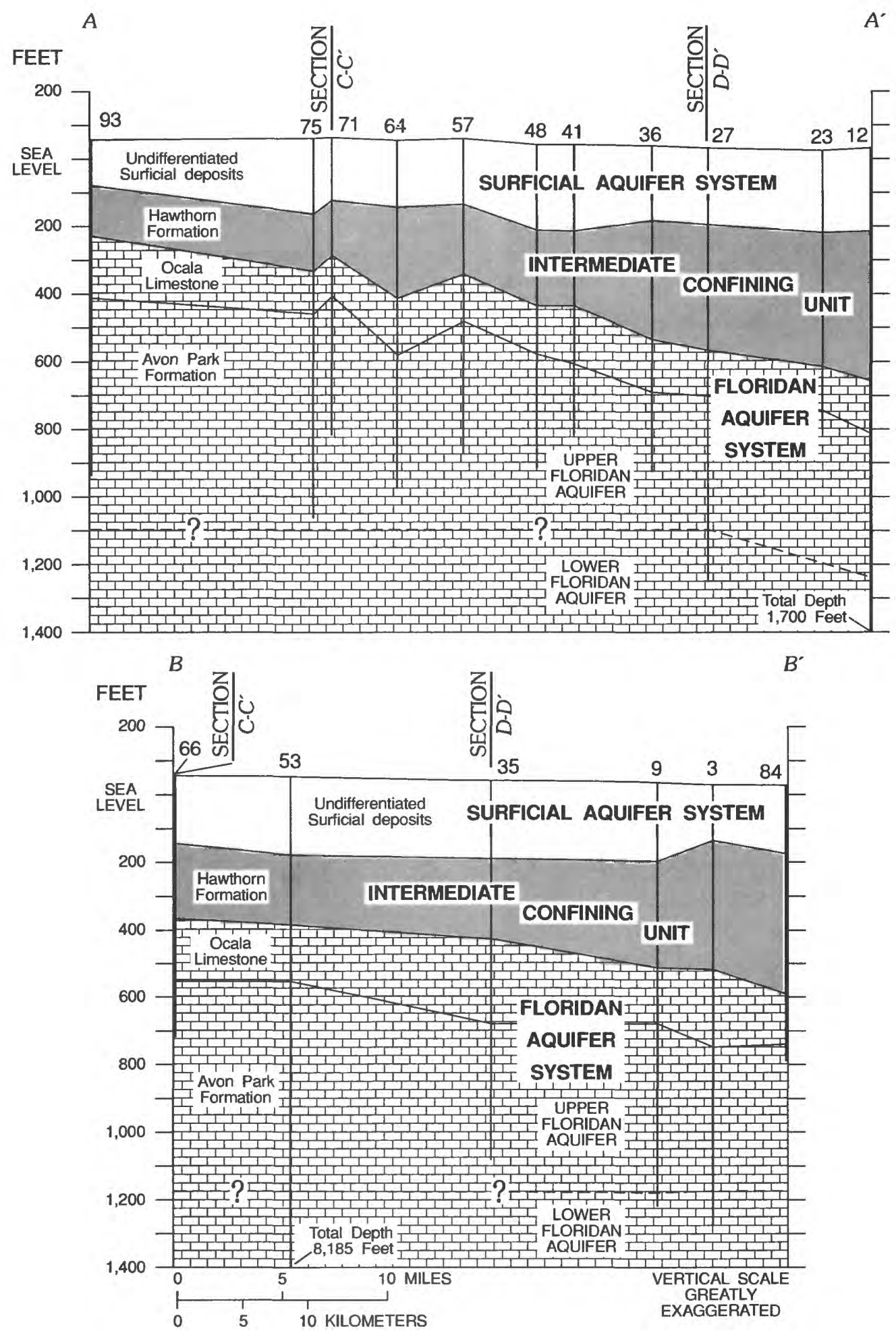

Figure 6. Hydrogeologic sections A-A' and B-B'. 

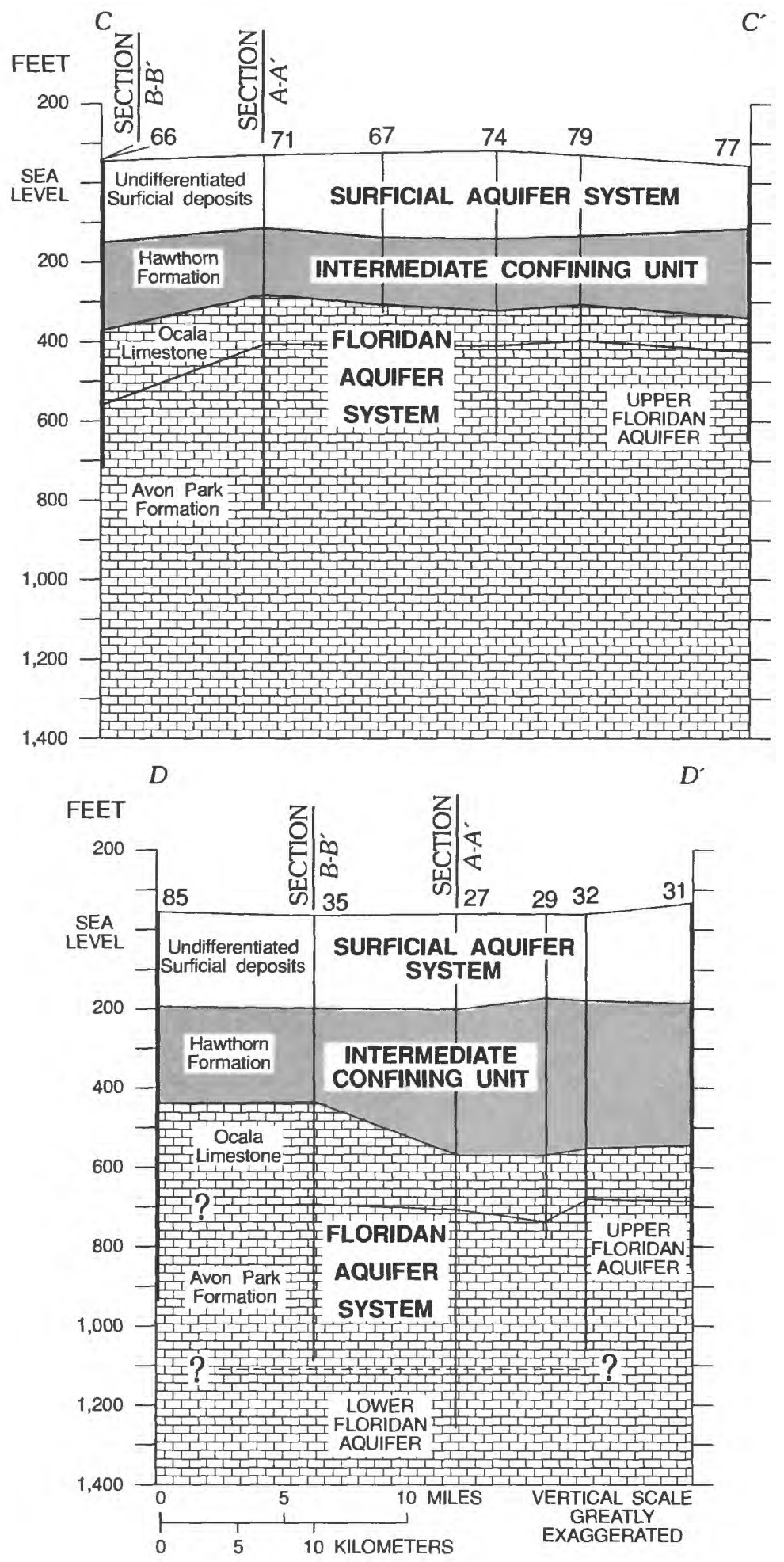

Figure 7. Hydrogeologic sections C-C' and D-D'. 


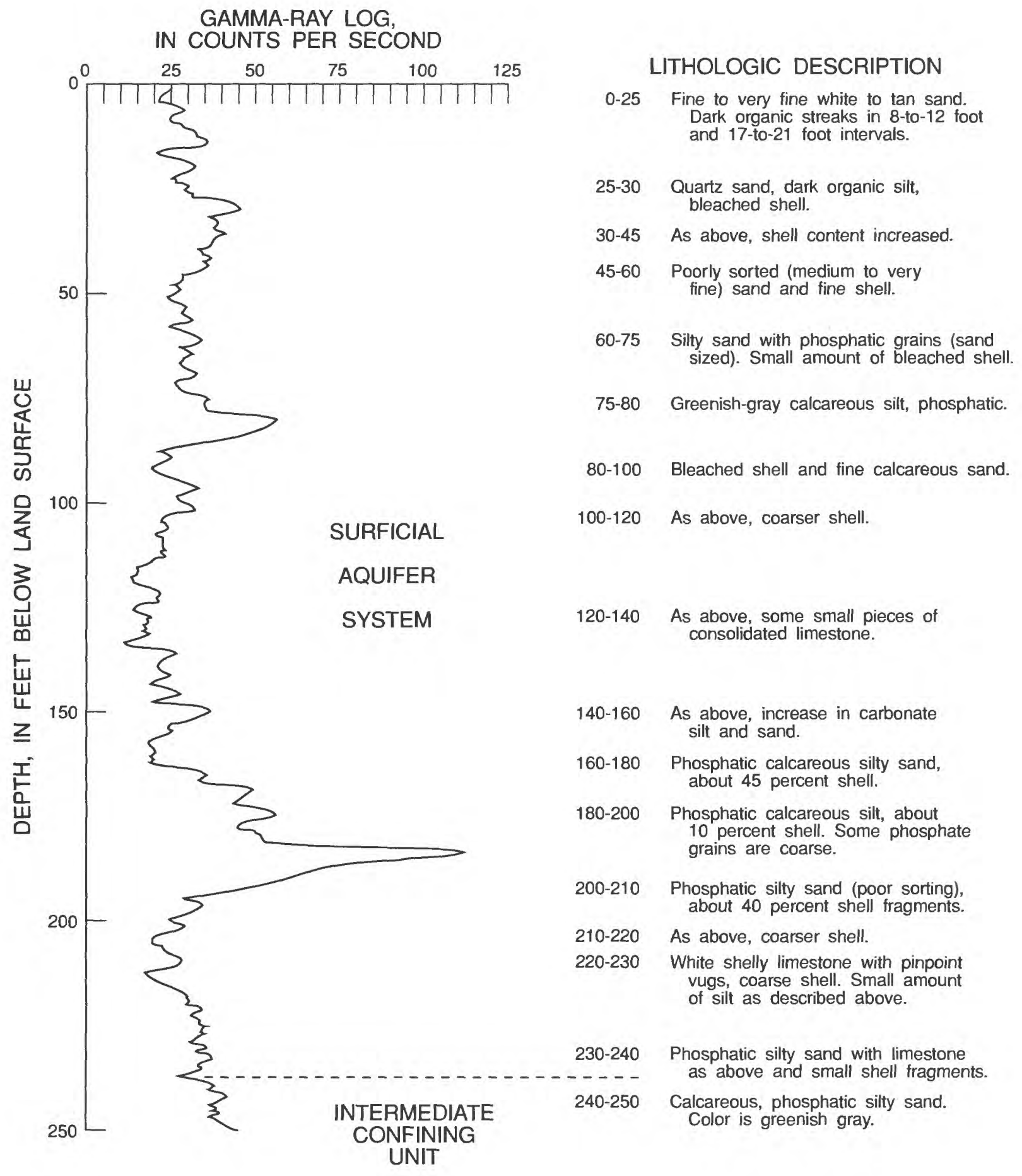

Figure 8. Gamma-ray log and lithologic description of well 23. (Gamma-ray log by the U.S. Geological Survey. Lithologic description by the South Florida Water Management District. Location of well shown in figure 5.) 


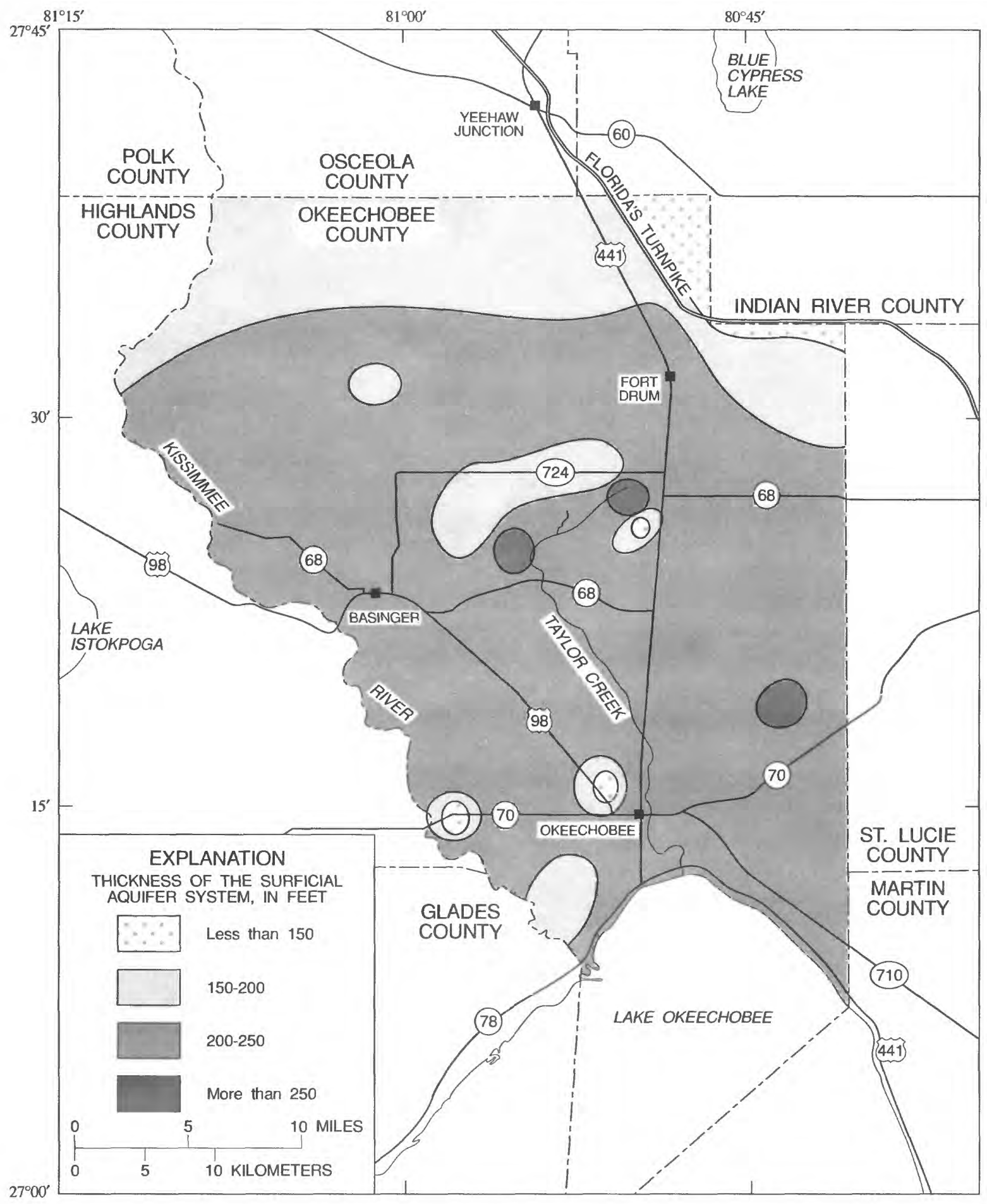

Figure 9. Thickness of the surficial aquifer system, Okeechobee County, Fla. 


\section{Hydraulic Properties}

The surficial aquifer system generally is unconfined, although the permeable layers of the middle and lower zones can be semiconfined where they are overlain by beds of low permeability. Hydraulic and aquifer characteristics, such as permeability and the thickness of the silt, clay, sand, and shell layers, affect the yield of wells that tap the aquifer system.

In Okeechobee County, yields from wells that tap the surficial aquifer system range from about 10 to more than $400 \mathrm{gal} / \mathrm{min}$ (South Florida Water Management District, West Palm Beach, Fla.). The larger yields are from wells that are deep enough to tap the two lower zones of the aquifer system where a thick layer of the highly productive coarse sand and shell zone is present. The smaller yields are from wells that tap fine sand and silt layers within the uppermost part of the surficial aquifer system or where no highly permeable zones are present. Specific capacities (well discharge per unit of drawdown) calculated from completion reports (South Florida Water Management District, unpub. data) of wells that tap the surficial aquifer system in Okeechobee County range from about 3 to about 50 (gal/min)/ft and average about $10(\mathrm{gal} / \mathrm{min}) / \mathrm{ft}$. Specific capacities tend to be highest in wells that tap thick layers of the middle permeable zone. No data on transmissivity or storativity of the surficial aquifer system are available.

\section{Recharge and Discharge}

The surficial aquifer system is recharged by infiltration of rainfall and downward percolation of irrigation waters applied to the land surface. The aquifer system receives no recharge from the Floridan aquifer system in the parts of the county where the artesian heads of the Floridan aquifer system are below the water table in the surficial aquifer system. In areas where the artesian heads of the Floridan aquifer system are above land surface, little recharge occurs from the underlying Floridan aquifer system to the surficial aquifer system because the intermediate confining unit separating them is thick and has low permeability, thereby limiting upward leakage. In some areas of the county, surface discharge from free-flowing wells that tap the Floridan aquifer system recharges the surficial aquifer system.

Discharge from the surficial aquifer system occurs as seepage to surface-water bodies, evapotranspiration, recharge to the Floridan aquifer system where the water table is above the artesian heads of the lower system, and withdrawals from wells.

Waters stored in the surficial aquifer system are considered to be recent in origin. Age dating by means of tritium analyses can be used to determine whether rainfall has recharged the aquifer system within the last 40 years. Tritium is the radioactive isotope of hydrogen $\left({ }^{3} \mathrm{H}\right)$ with a half-life of 12.43 years (Ostlund and Dorsey, 1977). High concentrations of tritium were not present in precipitation in Florida until after the atmospheric testing of hydrogen bombs during the early- to mid-1950's. Tritium concentrations in rainfall at Ocala, Fla., peaked in 1963 at 1,190 tritium units (TU) (U.S. Geological Survey, unpub. data, 1953-91). Concentrations of tritium in rainfall at Ocala, Fla., vary seasonally and currently range from 3 to $15 \mathrm{TU}$. Ground water containing tritium in concentrations of $1 \mathrm{TU}$ or less generally is considered to be older water that has not mixed with recharge water of recent (post 1950) origin.

Ground-water samples from two wells that tap the surficial aquifer system were analyzed for tritium. Well 6, about $60 \mathrm{ft}$ deep, yielded water containing $14 \mathrm{TU}$; well 55, about $120 \mathrm{ft}$ deep, yielded water containing 6.9 TU. These tritium concentrations are within the concentration range of 5 to $20 \mathrm{TU}$ detected in water samples from most surficial aquifer system wells in Florida (Swancar and Hutchinson, 1992). These results indicate that water in the surficial aquifer system in Okeechobee County is less than 40 years old.

\section{Water Quality}

The quality of water in the surficial aquifer system is particularly important in Okeechobee County because most of the domestic and public water-supply wells tap this aquifer system. The variability of the water quality in the aquifer system is the result of local and regional ground-water movement, the geology of the zone that the wells tap, the quality and quantity of the recharge water, and geochemical reactions within the aquifer system.

Results of water-quality analyses of samples collected by USGS personnel in 1990 from four wells that tap the surficial aquifer system are listed in table 2. Also listed for comparison in table 2 are the ranges of values for water-quality data for samples from 46 wells that tap the surficial aquifer system in the county (State of Florida Department of Health and Rehabilitative Services, unpub. data, 1989-91). 
Table 2. Quality of water from wells that tap the surficial aquifer system in Okeechobee County, Fla.

[Samples collected and analyzed by U.S. Geological Survey personnel unless otherwise stated. Concentrations are in milligrams per liter unless otherwise stated. <, less than; $\mu \mathrm{g} / \mathrm{L}$, micrograms per liter; --, no data]

\begin{tabular}{|c|c|c|c|c|c|c|c|}
\hline \multirow[t]{2}{*}{$\begin{array}{l}\text { Constituent or } \\
\text { physical property }\end{array}$} & \multirow{2}{*}{$\begin{array}{l}\text { Well } 6 \\
\frac{(60 \mathrm{ft} \text { deep })}{02-28-90}\end{array}$} & \multirow{2}{*}{$\begin{array}{c}\text { Well } 30 \\
(230 \mathrm{ft} \text { deep }) \\
07-25-90\end{array}$} & \multirow{2}{*}{$\begin{array}{l}\text { Well } 45 \\
(60 \text { Lt deep })\end{array}$} & \multirow{2}{*}{$\begin{array}{c}\text { Well } 55 \\
(120 \mathrm{ft} \text { deep }) \\
03-01-90\end{array}$} & \multicolumn{3}{|c|}{$\begin{array}{l}\text { Summary of values for } \\
\text { samples from } 46 \text { wells } \\
\text { collected and analyzed } \\
\text { by the State of Florida }\end{array}$} \\
\hline & & & & & Minimum & Median & Maximum \\
\hline $\begin{array}{l}\text { Specific conductance, in } \\
\text { microsiemens per } \\
\text { centimeter at } 25^{\circ} \mathrm{C}\end{array}$ & 1,580 & 607 & 680 & 505 & 189 & 689 & 3,600 \\
\hline Calcium & 310 & 93 & 100 & 95 & 66 & 111 & 406 \\
\hline Chloride & 28 & 31 & 45 & 17 & $<10$ & 36 & 1,100 \\
\hline Magnesium & 24 & 8.8 & 8.8 & 1.6 & 1.6 & 7.7 & 59.7 \\
\hline Potassium & 4.7 & 2.6 & 1.4 & .7 & .2 & 1.6 & 26.3 \\
\hline $\begin{array}{l}\text { Dissolved zinc, } \\
\text { in } \mu \mathrm{g} / \mathrm{L}\end{array}$ & 40 & - & - & 140 & $<50$ & 1,040 & 8,980 \\
\hline
\end{tabular}

Concentrations of dissolved iron in water from the surficial aquifer system ranged from less than 30 to $6,000 \mathrm{mg} / \mathrm{L}$. Water that contains high iron concentrations can stain clothing and fixtures and can have an unpleasant taste. Iron bacteria can clog the screens of wells that tap zones where iron concentrations are high.

Data in table 2 indicate that chloride concentrations in ground water from all the wells in the study area ranged from less than 10 to $1,100 \mathrm{mg} / \mathrm{L}$ with a median value of $36 \mathrm{mg} / \mathrm{L}$. The data also indicate that dissolved-solids concentrations in ground water ranged from 256 to $2,570 \mathrm{mg} / \mathrm{L}$ with a median value of $395 \mathrm{mg} / \mathrm{L}$.

Three potential pathways by which brackish water can enter the surficial aquifer system include (1) upward leakage from the Floridan aquifer system; (2) infiltration of water from land surface, either from free-flowing wells in the Floridan aquifer system or other sources of highly mineralized water, and (3) leakage through corroded Floridan aquifer system well casings. Although the surficial sediments in Okeechobee County are marine in origin, recharge from local rainfall probably has flushed all remnant seawater from the surficial aquifer system. Because of the thickness of the intermediate confining unit between the surficiai and Floridan aquifer systems, little natural upward leakage of brackish Floridan aquifer system water probably occurs, even in areas where the potentiometric surface of the Floridan aquifer system is above the water table of the surficial aquifer system.

The two most probable causes of brackishwater contamination of the surficial aquifer system in Okeechobee County are free-flowing wells that tap the Floridan aquifer system and leakage through 
corroded casings of Floridan aquifer system wells in discharge areas, illustrated in figure 10 . If a well that taps the Floridan aquifer system is free-flowing, brackish water can flow from the wellhead onto the land surface and then percolate down to the surficial aquifer system. If the casing of the Floridan aquifer system well is breached (because of corrosion) in the zones of the surficial aquifer system and the head in the Floridan aquifer system is above the water table, brackish water from the Floridan aquifer system can enter the surficial aquifer system through these breaches, regardless of whether the Floridan well is flowing, capped, or closed with a valve at land surface.

Areas in Okeechobee County where chloride concentrations are elevated in water within the surficial aquifer system are near free-flowing wells that tap the Floridan aquifer system. Chloride concentrations in water from the surficial aquifer system in these areas ranged from 86 to $1,100 \mathrm{mg} / \mathrm{L}$. Chemical

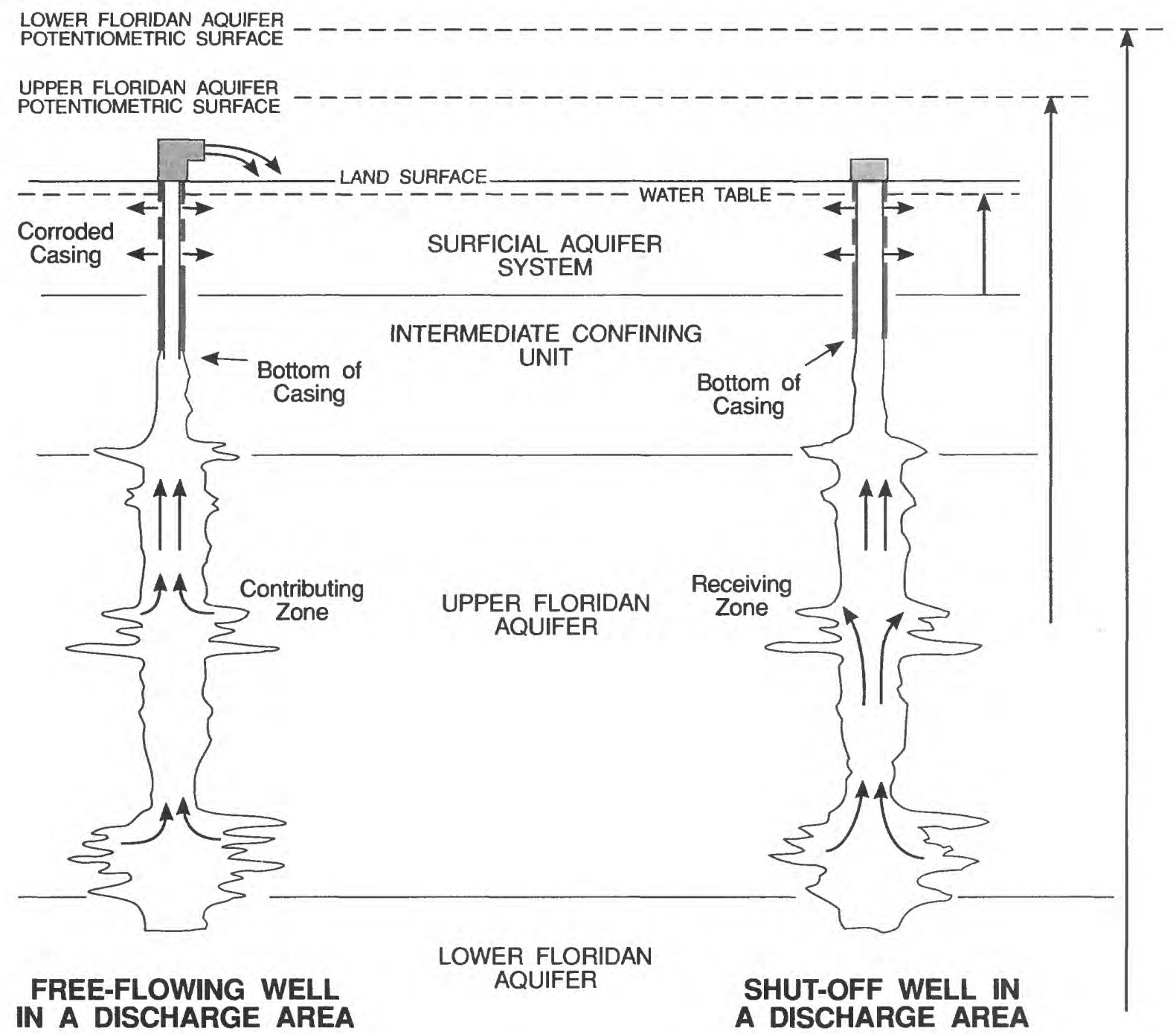

Figure 10. Ground-water movement from the Floridan aquifer system to the surficial aquifer system through wells. 
analyses of water from surficial aquifer system wells which yielded water with high concentrations of chlorides and dissolved solids indicated concentrations of other constituents typical of water from the Floridan aquifer system. An exception is the area at a closed landfill in central Okeechobee County where highly mineralized leachate from the landfill may be the cause of elevated chloride concentrations in ground water in the surficial aquifer system (Herr and Shaw, 1989).

Areas with high chloride concentrations in water from the surficial aquifer system in the southern part of Okeechobee County were recognized as early as 1941 (Parker and others, 1955). Parker reported water-quality data for the surficial aquifer system that indicated that ground water in several areas immediately adjacent to Lake Okeechobee contained elevated chloride concentrations. The analysis of more recent data from the State of Florida (Department of Health and Rehabilitative Services, unpub. data, 1989-91), indicates that these areas of elevated chloride concentrations still exist and that additional areas have been detected through more intensive sampling.

\section{Floridan Aquifer System}

The Floridan aquifer system consists of limestone and dolomitic limestone and ranges from 2,700 to 3,000 ft in thickness in Okeechobee County. The top of the Floridan aquifer system is defined as the first occurrence of vertically persistent, permeable, consolidated, carbonate rocks, which corresponds to the Ocala Limestone in most of the county. The top of the Floridan aquifer system is highest in the northern part of the study area (fig. 11) where it is about $300 \mathrm{ft}$ below sea level, or about $350 \mathrm{ft}$ below land surface. The top of the aquifer dips to almost $700 \mathrm{ft}$ below sea level in the southeastern part of the county.

One fault and one trough in the top of the Floridan aquifer system in Okeechobee County are shown by the structure contours in figure 11 . The fault line in the northwestern part of the county was inferred by Miller (1986) and has been extended slightly south of the original line indicated in Miller's report. The trough in the southeastern part of the county appears to be oriented northwest to southeast.

\section{Hydrogeologic Framework}

In most of central and northern Florida, the Floridan aquifer system is divided on the basis of the vertical occurrence of two zones of relatively high permeability (Tibbals, 1990). These zones are referred to as the Upper Floridan and Lower Floridan aquifers and are separated by a less permeable limestone and dolomitic-limestone sequence referred to as the middle semiconfining unit. Logs and driller's notes indicate that the middle semiconfining unit in Okeechobee County may be fractured and can be more productive than the Upper Floridan aquifer. Limestones present in the Ocala Limestone and upper part of the Avon Park Formation are dense in most parts of the county. Therefore, the Upper Floridan aquifer and middle semiconfining unit are considered to be one waterbearing zone.

The Lower Floridan aquifer has three major water-bearing zones with permeability increasing with depth. The zones are separated by beds of lower permeability. The upper zone is in the lower part of the Avon Park Formation and is at a depth of about 900 to $1,200 \mathrm{ft}$ below land surface. The upper zone is tapped by several of the deeper wells in the area. The top of the upper zone generally corresponds to the top of the freshwater-brackish water interface $(\mathrm{CH} 2 \mathrm{M}-\mathrm{Hill}$, Inc., 1989). The middle zone, which is about 1,500 to $2,000 \mathrm{ft}$ below land surface and is in the upper part of the Oldsmar Formation, probably is more permeable than the upper zone. However, wells that tap this layer yield water that is too salty for either public supply or agricultural irrigation (CH2M-Hill, 1989). The third and deepest zone of high permeability is the Boulder Zone and occurs about 2,500 to $3,000 \mathrm{ft}$ below land surface in Okeechobee County (Miller, 1986). This zone is used in south Florida and along the east coast of Florida for deep-well injection of treated sewage. Deep wells have not been drilled in the county to specifically test the aquifer properties of the Boulder Zone, however, drilling records for oil wells indicate the presence of a highly permeable zone in some parts of the county.

Most wells that tap the Floridan aquifer system in Okeechobee County are between 750 and $1,200 \mathrm{ft}$ deep. Most well casings extend to depths of 300 to $500 \mathrm{ft}$. In the northeastern part of the county, wells are drilled to shallower depths of 600 to $700 \mathrm{ft}$ to avoid the brackish water that is present at greater depths. 


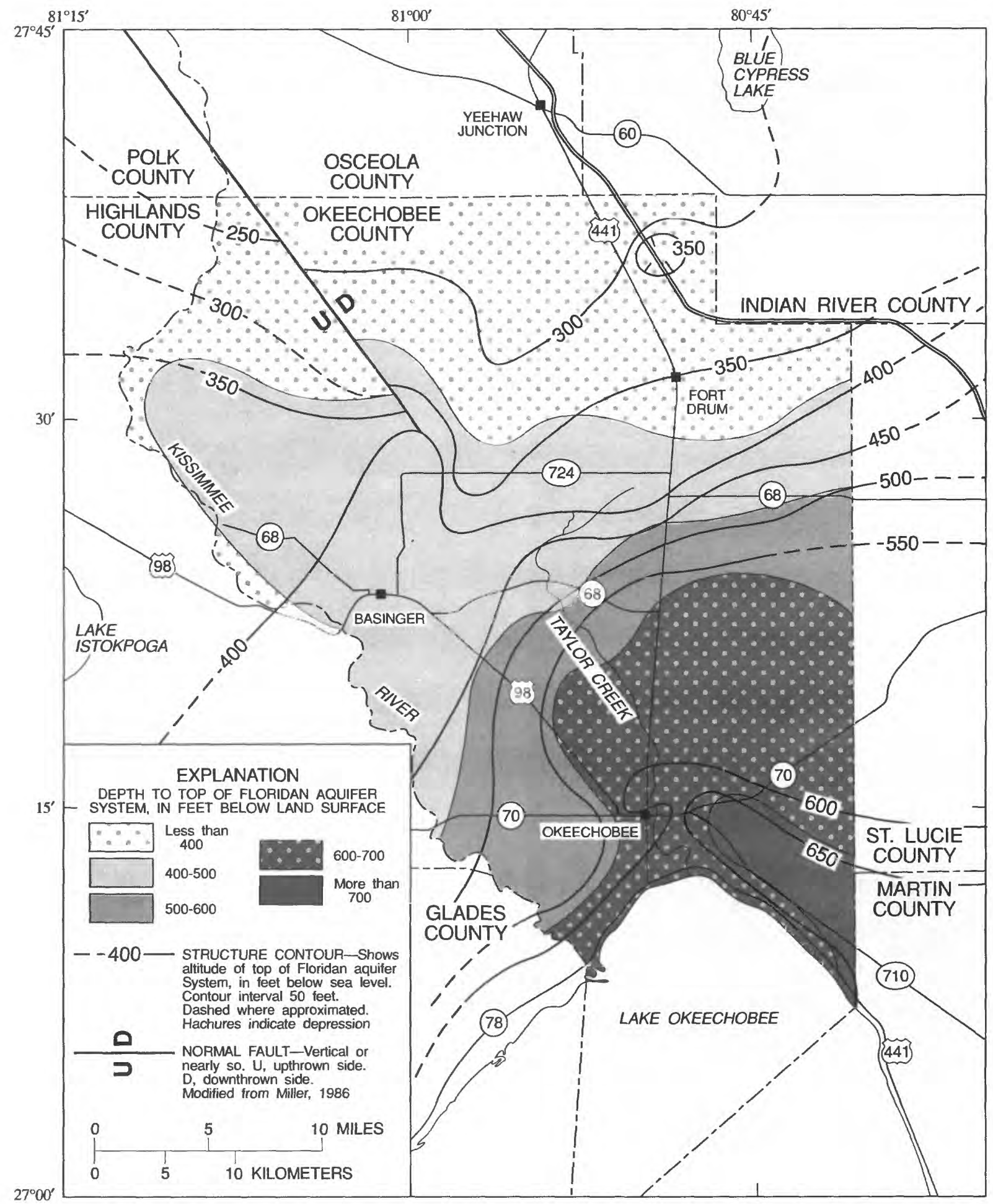

Figure 11. Altitude of and depth to the top of the Floridan aquifer system. 
Many wells tap the limey clays and shelly phosphatic layers of the intermediate confining unit as well as the Floridan aquifer system. In some places, these clays have swelled and intruded into the open hole, thus reducing flow from some wells. Current drilling regulations imposed by water management districts in Florida require casings to be set to the top of the Floridan aquifer system which, in most of the county, is the top of the white, foraminiferous Ocala Limestone.

\section{Potentiometric Surface}

The first map of the potentiometric surface of the Upper Floridan aquifer in Okeechobee County was prepared by Stringfield (1936), who used water levels from wells measured during 1933-35. Upper Floridan aquifer potentiometric-surface maps of central Florida have been published since 1975 on a semiannual basis by the USGS in cooperation with various State agencies and State water management districts.

The estimated potentiometric surface prior to development by pumping (Tibbals, 1990), based on the water levels measured by Stringfield (1936) in the early 1930's, is shown in figure 12. The September 1990 potentiometric surface (Spechler and others, 1991) is also shown in figure 12. A comparison of the maps indicates that in Okeechobee County, the Upper Floridan aquifer potentiometric surface has declined about $10 \mathrm{ft}$ from levels measured in the 1930's.

Seasonal fluctuations in the potentiometric surface from dry season to wet season generally range from 1 to $4 \mathrm{ft}$. Periodic water levels, measured since 1951 in well 22 at Okeechobee and since 1976 in well 72 at Fort Drum, are shown in figure 13. Water levels since 1966 in well 22 have ranged from 6 to more than $10 \mathrm{ft}$ below the first water level measured in 1951 and currently fluctuate about $2 \mathrm{ft}$ seasonally. Water levels in well 72 fluctuate about 1 to $3 \mathrm{ft}$ seasonally. There are no water levels shown between 1983 and 1985 for well 72 because records indicate that the casing may have been blocked for that period, and published water levels may be artificially high.

\section{Hydraulic Properties}

The hydraulic properties of the rock strata within the Floridan aquifer system vary with depth in the system. In most parts of Florida, the permeability of the Upper Floridan aquifer is reported to be generally higher than that of the Lower Floridan aquifer (Miller,
1986, p. B54). However, several aquifer tests (CH2M-Hill, 1989; Shaw and Trost, 1984a,b) and driller's notes indicate an increase in the permeability of the Floridan aquifer system with depth in most areas of Okeechobee County.

The most productive zones yielding freshwater probably are in the upper and middle parts of the Avon Park Formation. In most of the county, the Lower Floridan aquifer is more productive than the Upper Floridan, but the aquifer generally yields brackish water. Yields from wells that tap the Upper Floridan aquifer range from about 50 to $1,500 \mathrm{gal} / \mathrm{min}$. Wells that tap the Lower Floridan aquifer yield as much as $6,500 \mathrm{gal} / \mathrm{min}$ (CH2M-Hill, 1989). Transmissivity is a measure of the rate at which water moves through a unit width of an aquifer under a unit hydraulic gradient. Generally, larger transmissivity values indicate a more productive aquifer. Four single-well recovery tests were performed during this study to determine transmissivity of the Upper Floridan aquifer using the Theis Recovery equation (Theis, 1935). Plots of data from these tests are shown in figure 14. One well was pumped (fig. 14A, test 1) and three wells were continuously free-flowing (figs. 14B-D, tests 2 through 4). The wells used for the aquifer tests were open to most of the thickness of the Upper Floridan aquifer. Results of these tests indicated transmissivities that ranged from 1,900 to 6,900 .

Specific capacity tests were performed on several wells during this study. Table 3 lists all values and pertinent data from the wells. Results from the aquifer tests and several specific capacity tests at various depths in wells that were being drilled, indicate that the middle part of the Avon Park Formation generally has a greater transmissivity than shallower water-bearing units.

Locations of wells and results of aquifer and specific capacity tests performed by the USGS, the SFWMD, and CH2M-Hill are shown in figure 15 . Transmissivities generally are less than $10,000 \mathrm{ft}^{2} / \mathrm{d}$ within the Upper Floridan aquifer in most of the study area. Results from the aquifer tests indicate that, relative to other areas in the State (Tibbals, 1990), the transmissivity of the upper part of the Floridan aquifer system is low in most of Okeechobee County. Typical transmissivity values in much of Florida range from 100,000 to more than $1,000,000 \mathrm{ft}^{2} / \mathrm{d}$ for the Upper Floridan aquifer. Most wells that tap the Lower Floridan aquifer in Okeechobee County typically have an open hole through the entire thickness of the Upper 

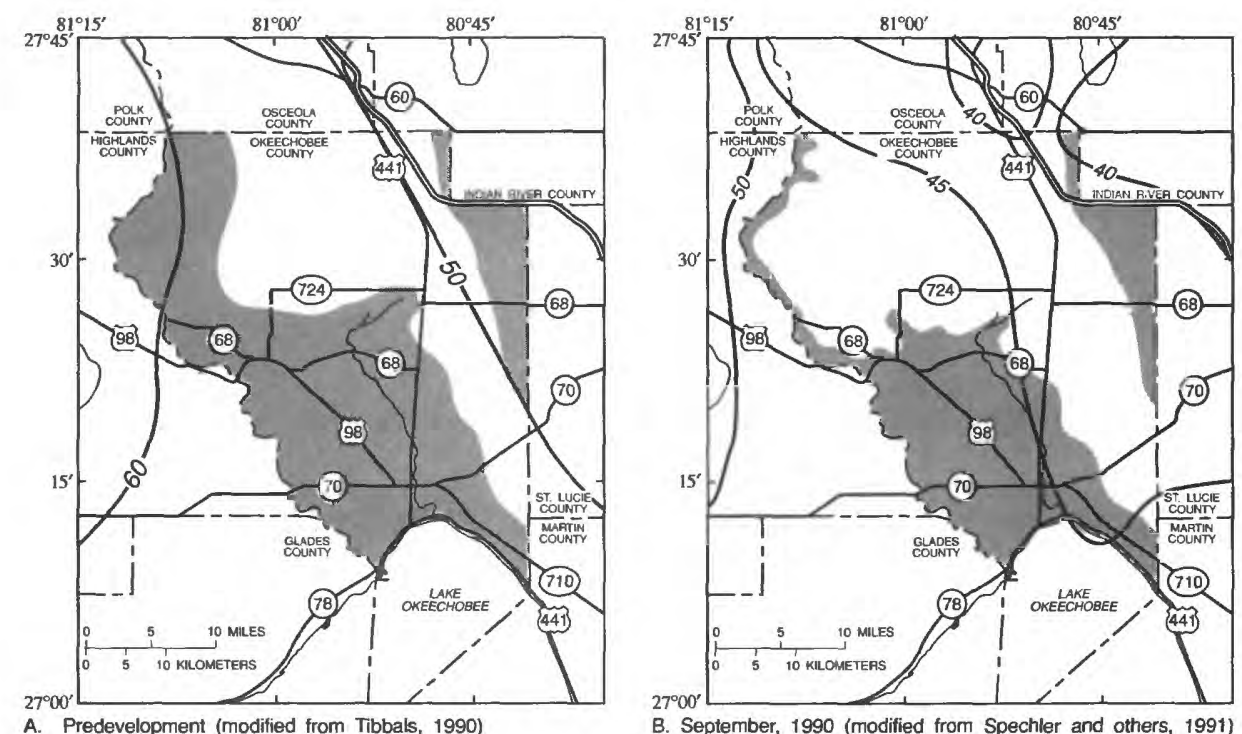

\section{EXPLANATION}

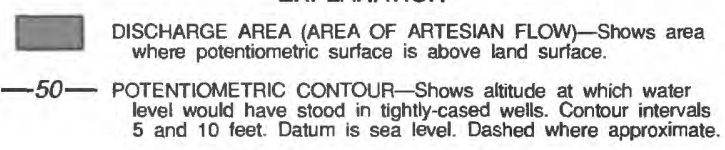

Figure 12. Potentiometric surfaces of the Upper Floridan aquifer for (a) predevelopment and (b) September 1990 and areas of natural discharge from the Floridan aquifer system.

Well 22

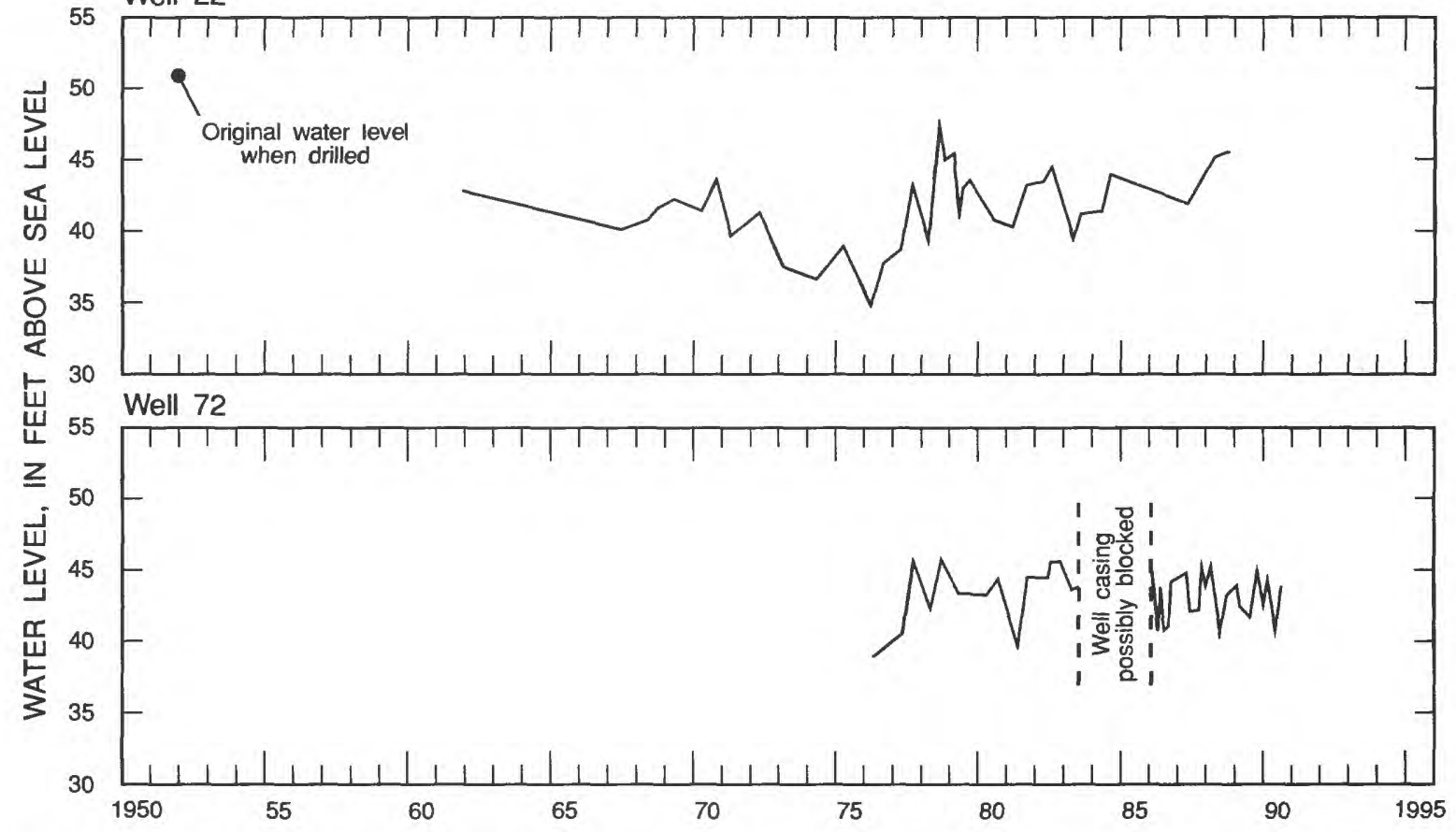

Figure 13. Long-term water-level fluctuations in wells 22 and 72 . (Locations of wells shown in figure 5.) 

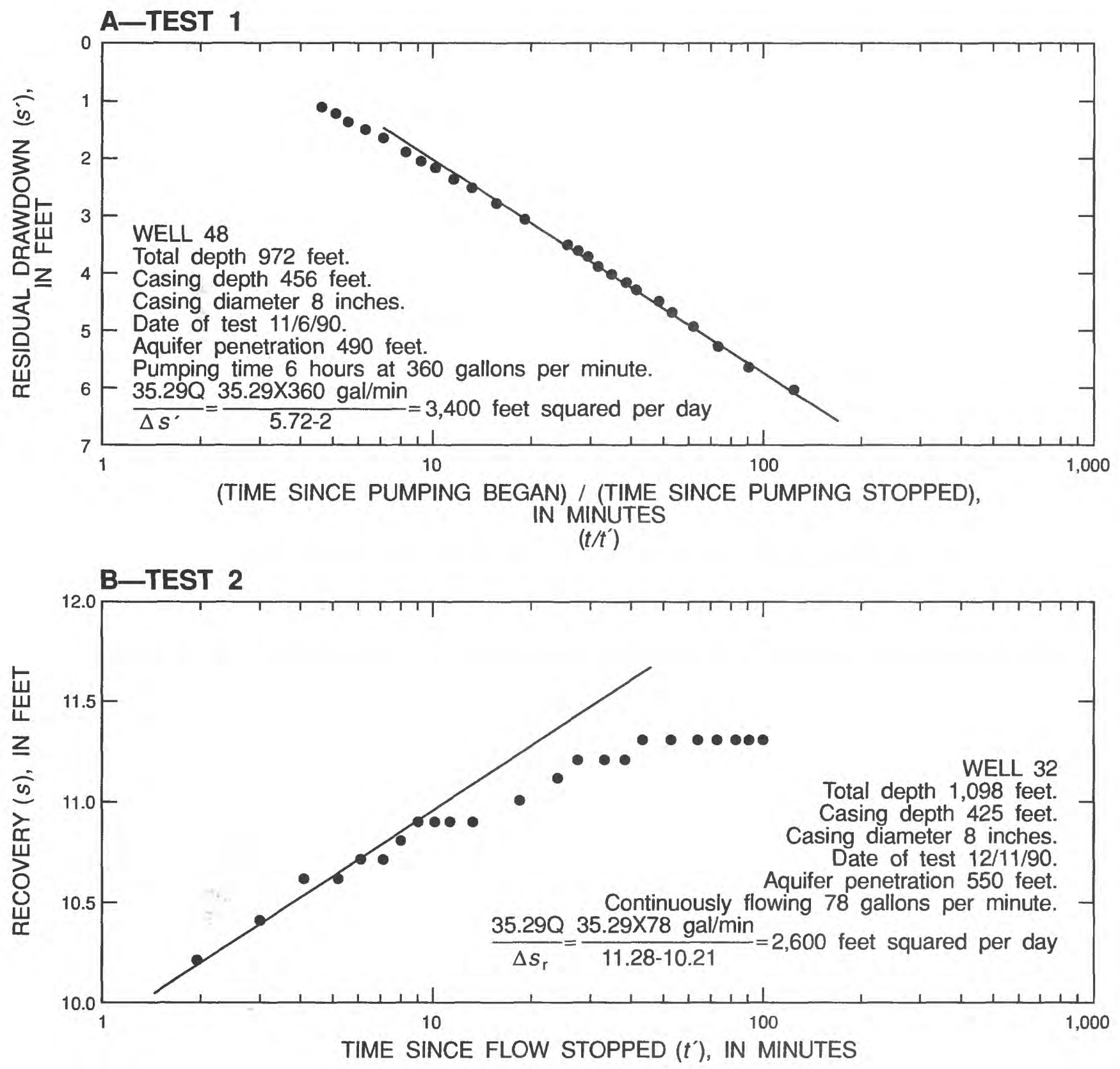

Figure 14. Results of single-well recovery tests in Okeechobee County, Fla. 

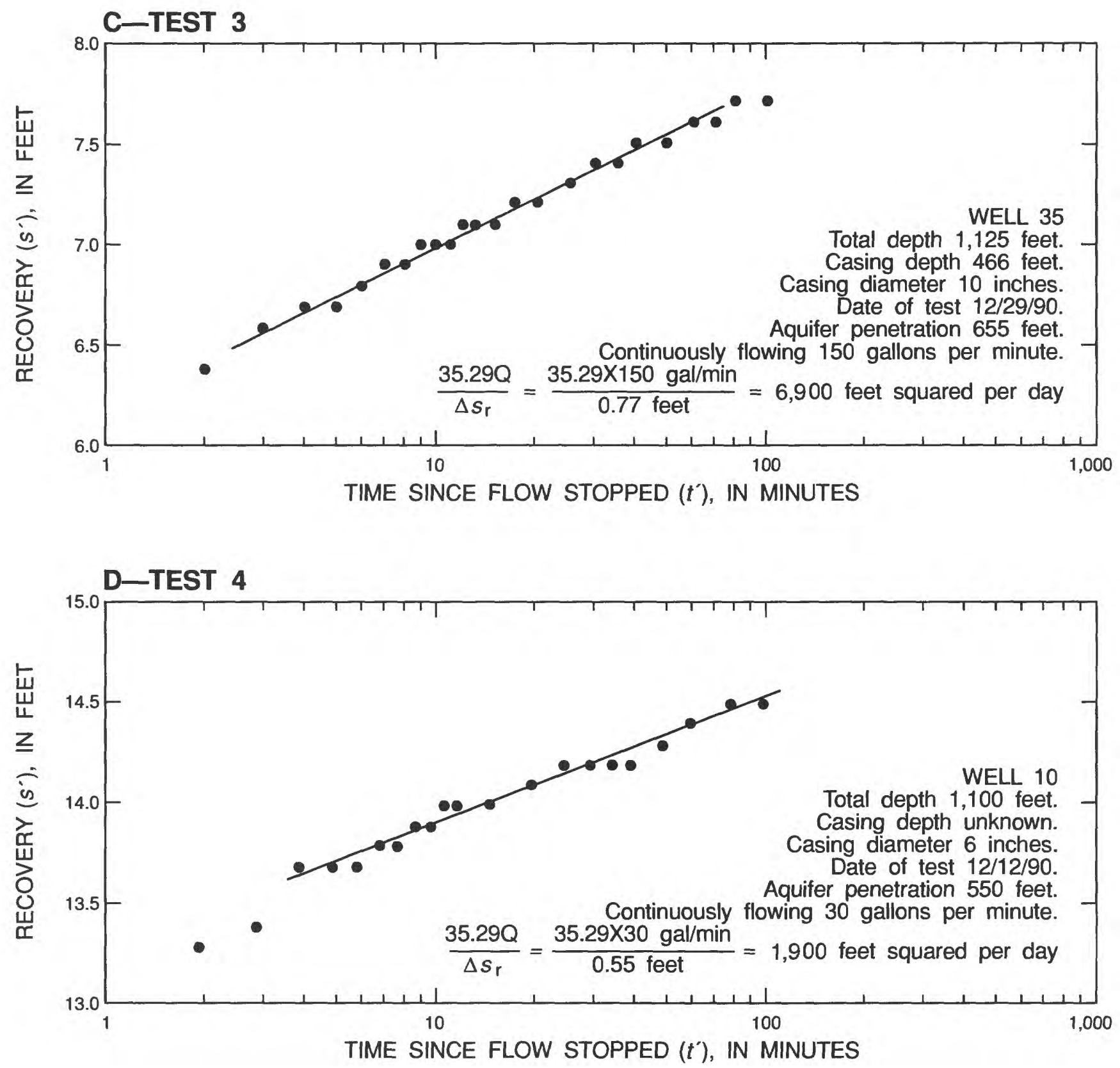

Figure 14. Results of single-well recovery tests in Okeechobee County, Fla.--Continued. 


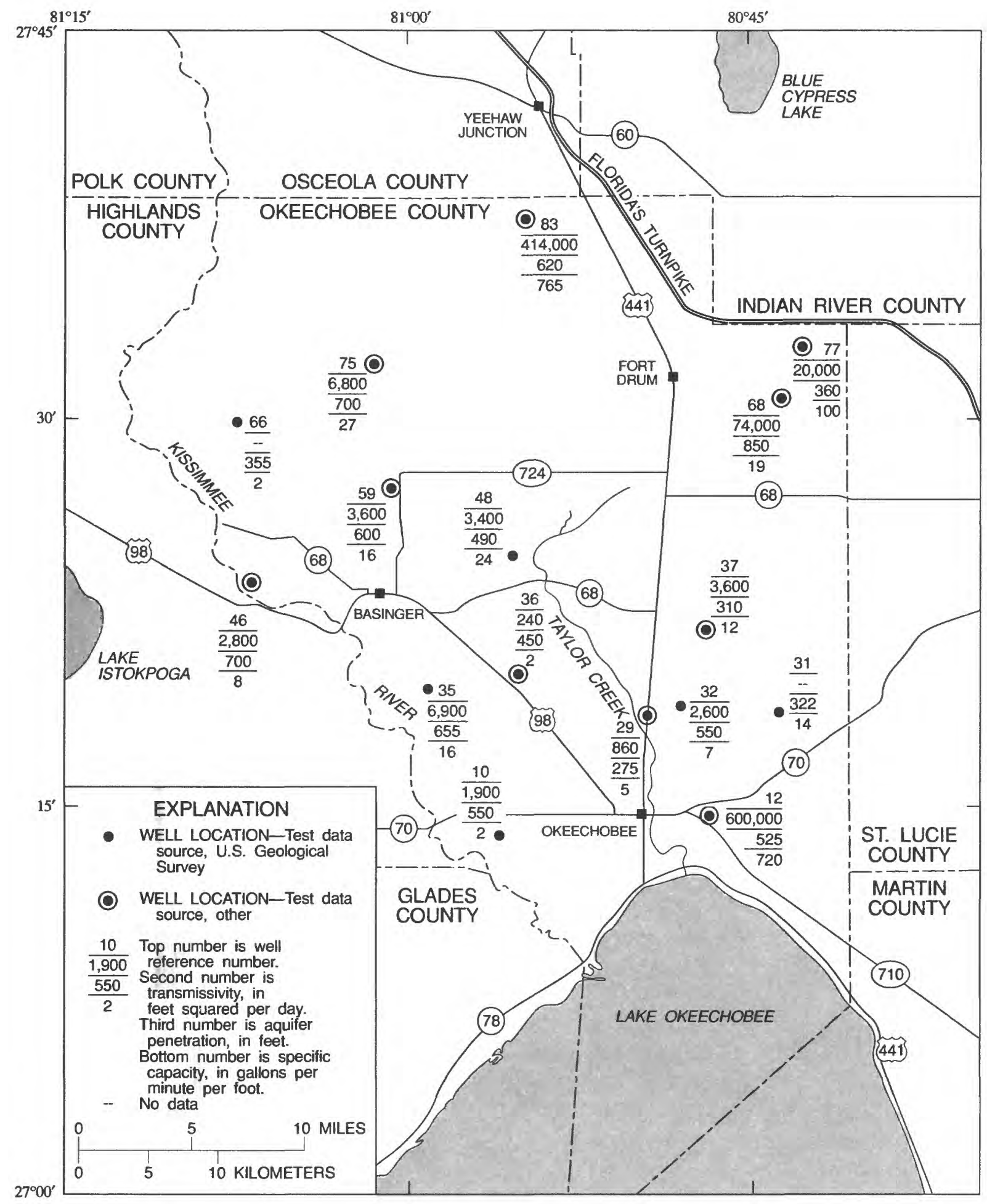

Figure 15. Transmissivities and specific capacities of the Floridan aquifer system, Okeechobee County, Fla. 
Table 3. Transmissivities of the Floridan aquifer system in Okeechobee County, Fla.

[U, Upper Floridan aquifer; L, Lower Floridan aquifer; --, no data]

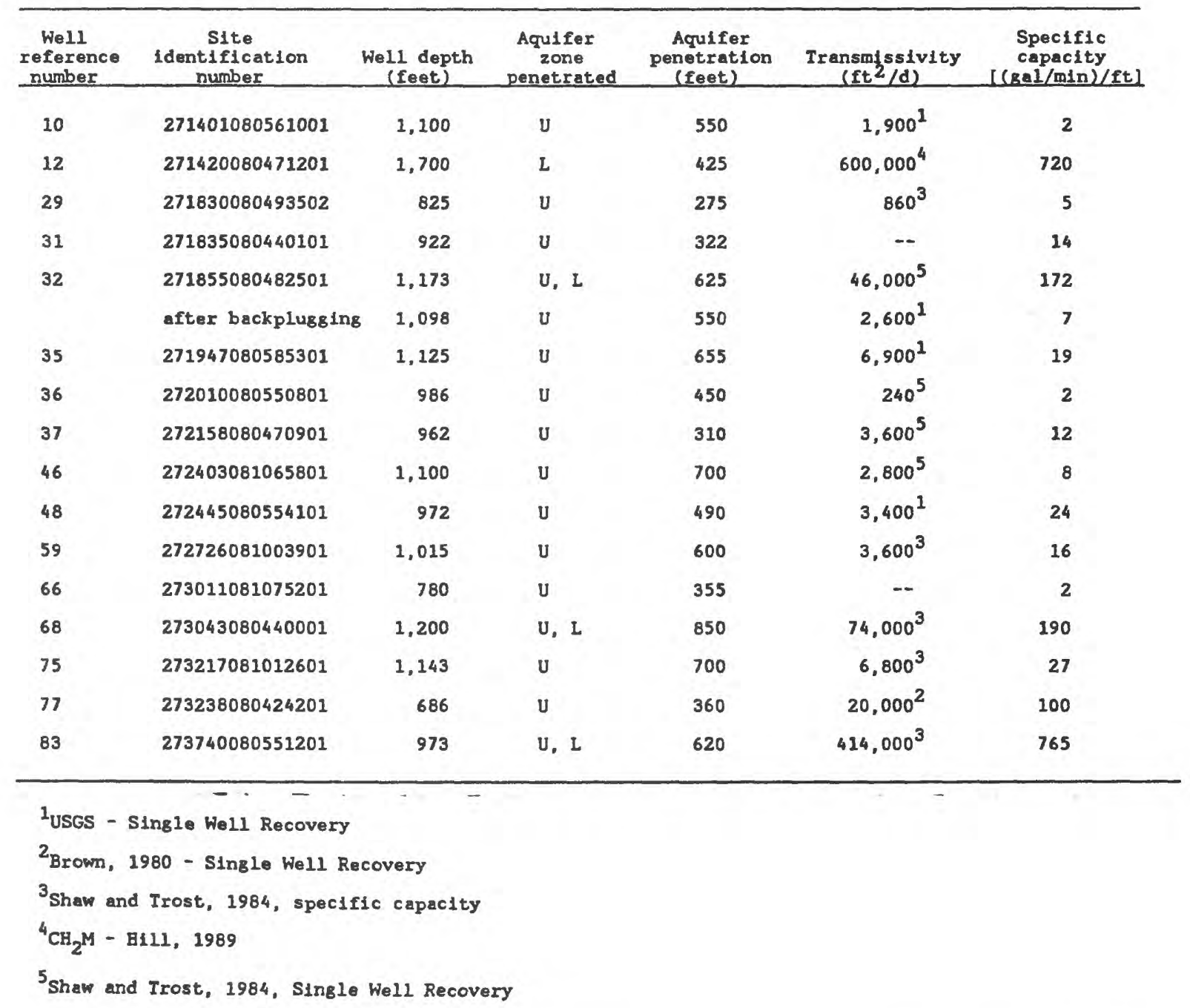

Floridan aquifer and through about $100 \mathrm{ft}$ of the Lower Floridan aquifer, thus the transmissivity values from these multiaquifer wells do not represent one zone. Two single-well recovery tests were performed on well 32: one in which the well had $625 \mathrm{ft}$ of open hole, including $75 \mathrm{ft}$ of the Lower Floridan aquifer at the bottom, and one in which the well had $550 \mathrm{ft}$ of open hole, after backplugging the bottom $75 \mathrm{ft}$. The transmissivity value decreased from $46,000 \mathrm{ft}^{2} / \mathrm{d}$ (Shaw and Trost, 1984a,b) to about $2,600 \mathrm{ft}^{2} / \mathrm{d}$ (fig. 14B, test 2). Although the well yield was significantly reduced, the main reason for backplugging the well was to lower chloride concentrations in the water from the well. Chloride concentrations decreased from $1,800 \mathrm{mg} / \mathrm{L}$ to about $160 \mathrm{mg} / \mathrm{L}$ in water from well 32 after the well was backplugged.
Well 12 is cased through the Upper Floridan and taps the top $525 \mathrm{ft}$ of the Lower Floridan aquifer. The well, intended to be used for aquifer storage and recovery (CH2M-Hill, 1989), had a calculated transmissivity of about $600,000 \mathrm{ft}^{2} / \mathrm{d}$. This well is open to the upper and middle high-flow zones in the lower Avon Park Formation and the upper Oldsmar Formation.

\section{Recharge and Discharge}

Water enters, or recharges, the Floridan aquifer system in Okeechobee County by downward leakage from the surficial aquifer system through the intermediate confining unit to the Upper Floridan aquifer and by lateral inflow from adjacent areas. Recharge areas 
Table 4. Quality of water from wells that tap the Upper Foridan aquifer and from wells that tap the Upper and Lower Floridan aquifers in Okeechobee County, Fla., 1990-91.

[Concentrations are in milligrams per liter unless otherwise stated. $\mu \mathrm{g} / \mathrm{L}$, micrograms per liter]

\begin{tabular}{|c|c|c|c|c|c|c|c|c|}
\hline \multirow{2}{*}{$\begin{array}{l}\text { Constituent } \\
\text { or physical } \\
\text { property }\end{array}$} & \multicolumn{4}{|c|}{$\begin{array}{l}\text { Wells that tap the } \\
\text { Upper Floridan aquifer }\end{array}$} & \multicolumn{4}{|c|}{$\begin{array}{l}\text { Wells that tap the Upper } \\
\text { Floridan aquifer and } \\
\text { the Lower Floridan aquifer }\end{array}$} \\
\hline & $\begin{array}{l}\text { Number } \\
\text { of } \\
\text { samples }\end{array}$ & Minimun & Median & Maximum & $\begin{array}{l}\text { Number } \\
\text { of } \\
\text { samples }\end{array}$ & Minimum & Median & Maximum \\
\hline $\begin{array}{l}\text { Specific conductance, } \\
\text { microsiemens per } \\
\text { centimeter at } 25 \text { " C }\end{array}$ & 29 & 507 & 849 & 2,210 & 19 & 567 & 3,500 & 7,150 \\
\hline Dissolved solids & 21 & 317 & 546 & 1,360 & 12 & 357 & 1,660 & 4.560 \\
\hline Hardness as $\mathrm{CaCO}_{3}$ & 32 & 170 & 270 & 460 & 12 & 210 & 640 & 1,640 \\
\hline Calcium & 33 & 22 & 53 & 107 & 16 & 35 & 125 & 360 \\
\hline Chloride & 33 & 23 & 100 & 540 & 20 & 50 & 790 & 2,140 \\
\hline Magnesium & 33 & 6.9 & 32 & 55 & 16 & 27 & 75 & 183 \\
\hline Potassium & 31 & 1.3 & 5.7 & 13 & 15 & 4.8 & 15 & 28 \\
\hline Sodium & 31 & 17 & 57 & 320 & 15 & 36 & 450 & 1,110 \\
\hline Sulfate & 33 & .8 & 120 & 250 & 16 & 96 & 325 & 1,000 \\
\hline Strontium, in $\mu \mathrm{g} / \mathrm{L}$ & 30 & 460 & 10,500 & 33,200 & 13 & 9,200 & 27,500 & 42,000 \\
\hline
\end{tabular}

generally are in the central and northern parts of the county where the water table is higher than the potentiometric surface of the Upper Floridan aquifer.

The rate of recharge depends on the elevations of the water table and the potentiometric surface of the Upper Floridan aquifer, and the thickness and permeability of the confining beds. Computer-based model simulation (Tibbals, 1990, fig. 22) indicates that recharge rates are low in Okeechobee County, ranging from 0.2 to $1.0 \mathrm{in} / \mathrm{yr}$ or a maximum of about $50,000(\mathrm{gal} / \mathrm{d}) / \mathrm{mi}^{2}$ in the recharge areas. Recharge due to lateral inflow from adjacent areas probably is small because Upper Floridan aquifer gradients are relatively flat and transmissivities of the Upper Floridan aquifer are relatively low.

Discharge from the Floridan aquifer system in Okeechobee County occurs by diffuse upward leakage in discharge areas, through free-flowing wells in discharge areas, by pumped wells anywhere in the county, and by lateral outflow at the eastern boundary. Almost half the county is a discharge area. Rates of diffuse upward leakage derived by Tibbals (1990) range from 0.4 to $1.3 \mathrm{in} / \mathrm{yr}$ for discharge areas within Okeechobee County. In the discharge areas (fig. 12), wells that tap the Floridan aquifer system will flow at land surface.

\section{Water Quality}

The quality of water in the Floridan aquifer system varies areally within Okeechobee County but has remained fairly constant throughout most of the county since the 1930's. However, in some areas of the the county, brackish water has entered parts of the freshwater aquifer system.

Hydraulics and geology are two major factors affecting the natural quality of water in the Floridan aquifer system. The relatively flat hydraulic gradient, low transmissivities, and low recharge contribute to long residence time for the water within the aquifer system. As water moves through the aquifer system, it tends to become more highly mineralized as a result of the gradual dissolution of the rock 
material it contacts. Longer residence times typically result in higher degrees of mineralization of the aquifer water.

A third major factor affecting the quality of water from wells that tap both zones in the Floridan aquifer system is the mixing and chemical reaction of freshwater with the highly mineralized water that occurs at depth. Results of water-quality analyses of samples from wells that tap the Lower Floridan aquifer were compared with data for samples from wells that tap the Upper Floridan. Some of the well depths were unknown or were reported depths that were not confirmed. Some of the apparently anomalous water-quality data shown in figures in this report may be caused by a well being deeper or shallower than reported.

Concentrations of dissolved solids, sulfate, and chloride in water from wells that tap the Upper Floridan aquifer are shown in figures 16 through 18. Table 4 lists the ranges of values for selected waterquality constituents and physical properties in water from wells that tap the Upper Floridan aquifer and from wells that tap both the Upper and Lower Floridan aquifers.

The extent to which water is mineralized can be described by its dissolved-solids concentration. The upper recommended limit for dissolved-solids concentration is $500 \mathrm{mg} / \mathrm{L}$ for public water supply, but may be greater if no other maximum contaminant level is exceeded (Florida Department of State, 1989). The highest concentrations of dissolved solids are in the northeastern and south-central parts of Okeechobee County (fig. 16). Most of the highly mineralized water is the result of freshwater mixing with remnant seawater that entered the aquifer system during past geologic eras.

In the northeastern corner of the county, the high dissolved-solids concentrations mostly are the result of the upconing of brackish water. The upconing probably is caused by heavy pumping of the Floridan aquifer system for agricultural uses or by interborehole flow in deeper wells. The top of the Lower Floridan aquifer might be about $800-900 \mathrm{ft}$ below land surface in that area and wells (flowing or valved off) that tap both zones may provide a pathway for interborehole flow from the more permeable Lower Floridan aquifer to the Upper Floridan aquifer. Well-completion reports on file in the water management district offices indicate that many wells in the area are backplugged to reduce the mineralization of the water from these wells. Yields in backplugged wells also are reduced to about 25 percent of the original yield, which indicates that the wells probably received most of their yield from the Lower Floridan aquifer before backplugging.

In the south-central part of the county, the presence of brackish water in the Upper Floridan aquifer probably is the result of either incomplete flushing of ancient seawater or natural upward movement of underlying brackish water along hidden faults or joints in the geologic structure identified only as a trough in the top of the Floridan aquifer system.

Hardness is used to describe the resistance of water to produce a lather from soap. Hardness is expressed as an equivalent quantity of calcium carbonate and is classified in $\mathrm{mg} / \mathrm{L}$ as $\mathrm{CaCO}_{3}$, as soft $(0-60 \mathrm{mg} / \mathrm{L})$, moderately hard $(61-120 \mathrm{mg} / \mathrm{L})$, hard $(121-180 \mathrm{mg} / \mathrm{L})$ and very hard (greater than $180 \mathrm{mg} / \mathrm{L})(\mathrm{Hem}, 1985$, p. 57, 159). Hard water can cause problems in small-diameter pipes because of the buildup and sloughing of calcium deposits but does not substantially affect agricultural irrigation. Hardness in water in the Upper Floridan aquifer in Okeechobee County ranges from 170 to $460 \mathrm{mg} / \mathrm{L}$, but there is no apparent areal pattern of hardness.

Sulfate concentrations (fig. 17) range from about 1 to $250 \mathrm{mg} / \mathrm{L}$ in water from the Upper Floridan aquifer with the higher concentrations present in discharge areas in the southern part of Okeechobee County. The recommended upper limit for sulfate in public water supply is $250 \mathrm{mg} / \mathrm{L}$ (Florida Department of State, 1989). Sulfate is present in some rock minerals and also in ancient seawater. A bacterial process that reduces sulfate to bisulfide produces hydrogen sulfide gas. This gas causes the characteristic "rotten egg" odor of water from some wells.

Chloride is the predominant anion in seawater and is the reason for its salty taste. Chloride concentration is the most commonly used indicator of brackish water. The recommended upper limit for chloride concentrations in public water supplies in Florida is $250 \mathrm{mg} / \mathrm{L}$ (Florida Department of State, 1989). Water usually does not taste salty until concentrations exceed about $400 \mathrm{mg} / \mathrm{L}$. The highest chloride concentrations in water in the Upper Floridan aquifer generally are in the northeastern, south-central, and southwestern parts of Okeechobee County (fig. 18). Chloride concentrations in the northeastern part of the county are from "skimmer" wells, or wells that 


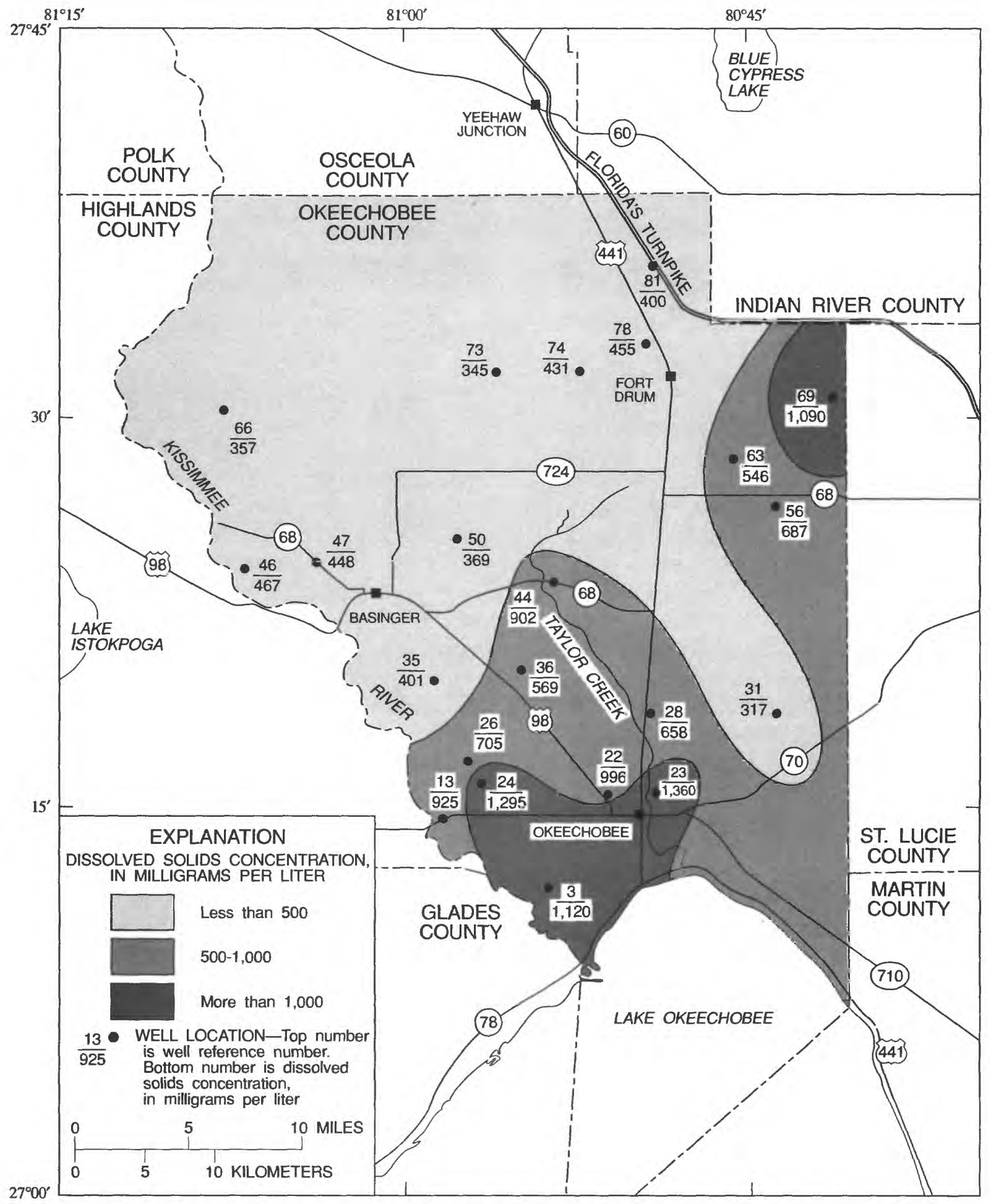

Figure 16. Dissolved-solids concentration in water from wells that tap the Upper Floridan aquifer, Okeechobee County, Fla. 


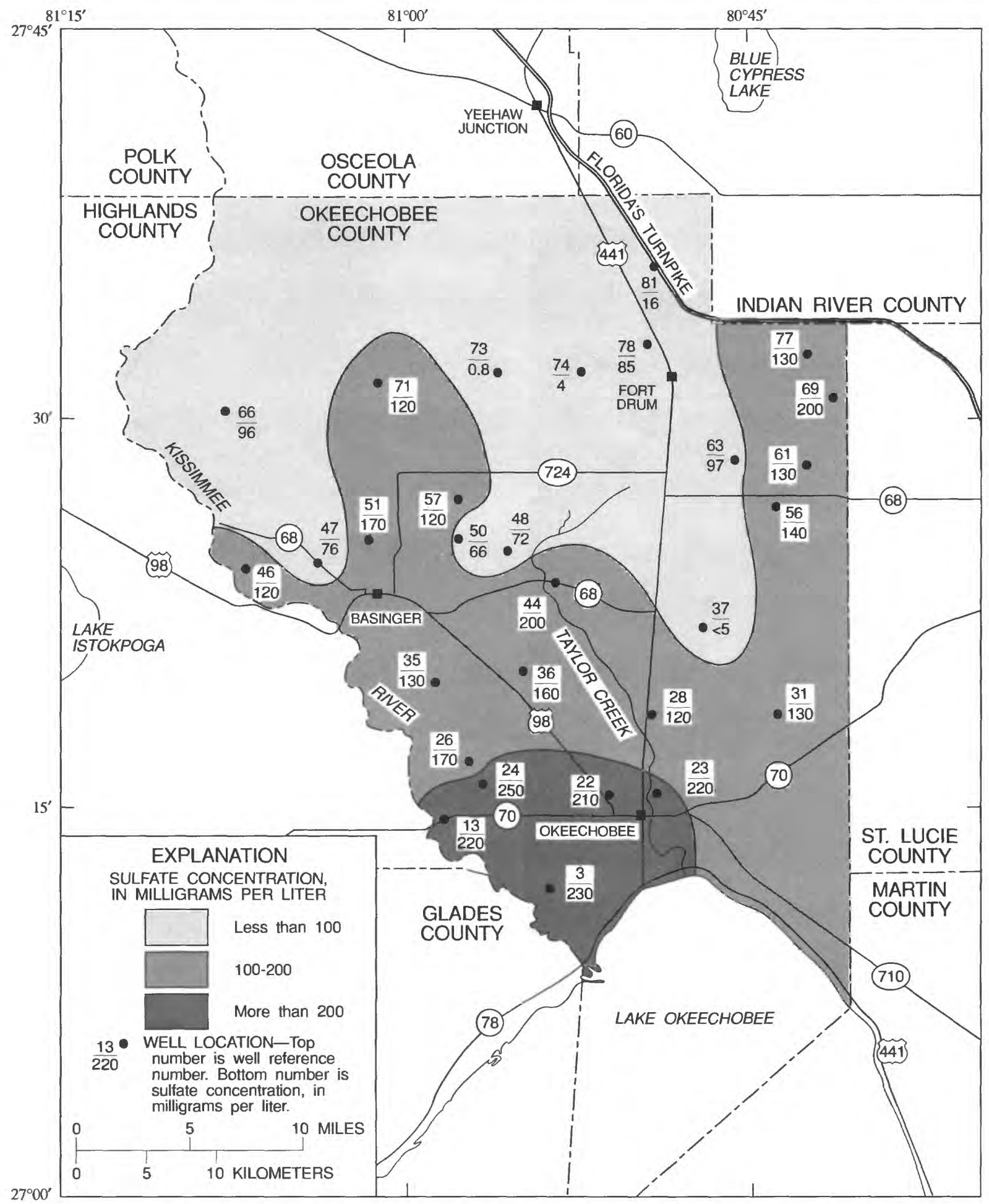

Figure 17. Sulfate concentration in water from wells that tap the Upper Floridan aquifer, Okeechobee County, Fla. 


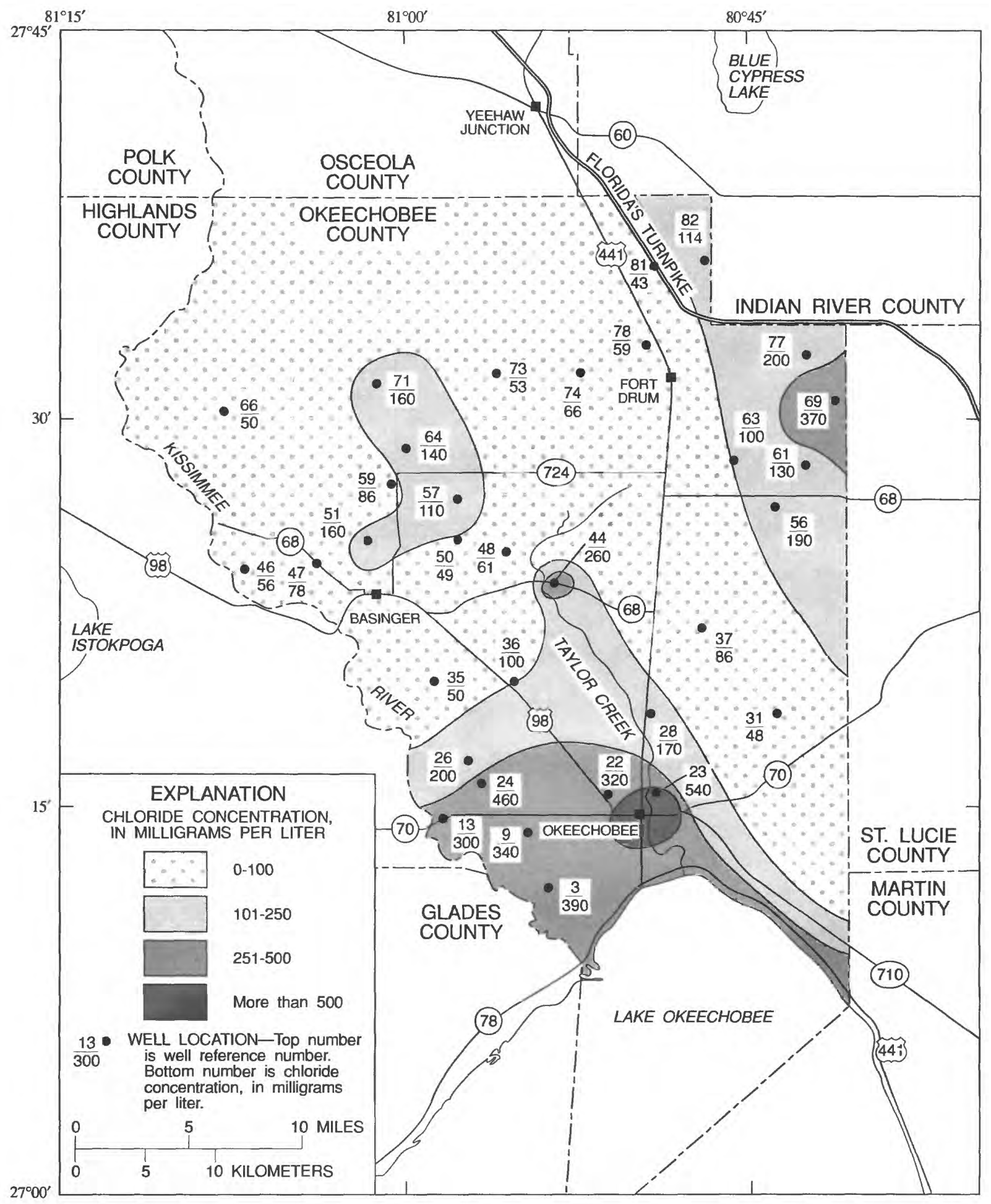

Figure 18. Chloride concentrations in water from wells that tap the Upper Floridan aquifer, Okeechobee County, Fla. 
have been drilled only into the top 100 to $200 \mathrm{ft}$ of the Upper Floridan aquifer because of known chloride problems in deeper parts of the aquifer.

The chloride concentrations in water in the Upper Floridan aquifer are, in part, a function of the amount of local recharge to the aquifer. The relation between land-surface altitude and chloride concentration is shown in figure 19. The potentiometric surface of the Upper Floridan aquifer is relatively flat across the county and typically ranges from 42 to $48 \mathrm{ft}$ above sea level. In areas where the landsurface altitude is higher than about $50 \mathrm{ft}$, the water table probably is above the potentiometric surface and the hydraulic gradient allows downward leakage of freshwater into the Floridan aquifer system. Chloride concentrations in water from the Upper Floridan aquifer typically are higher in the areas where land-surface altitude is below about $35 \mathrm{ft}$ (fig. 19). These areas commonly are discharge areas because the potentiometric surface of the Upper Floridan aquifer is above land surface.

Chemical composition of water from wells that tap the Floridan aquifer system are shown on the trilinear diagram in figure 20 . This diagram indicates similarities or differences in water types (Hem, 1985), but does not show differences in total ion concentrations. Two geochemical facies are indicated by two distinct trends in the trilinear diagram for water from the Upper Floridan aquifer (fig. 20). The two geochemical facies apparently are related to the physiographic location of the wells. Wells in the recharge areas (land-surface altitude above $50 \mathrm{ft}$ ) tend to yield water that is a calcium bicarbonate type, whereas wells in the discharge areas (landsurface altitudes below $35 \mathrm{ft}$ ) tend to yield water that is either a magnesium sulfate type or a sodium chloride type. Wells that also tap the Lower Floridan aquifer tend to yield water that is a sodium chloride type.

\section{Variations in chloride concentration with depth}

In Okeechobee County, chloride concentrations in water from wells that tap the Upper and Lower Floridan aquifers generally exceed the recommended upper limit for public water supply of $250 \mathrm{mg} / \mathrm{L}$ (fig. 21). Some of the wells that tap the Lower Floridan aquifer in the southern part of the county yield water with chloride concentrations exceeding $1,500 \mathrm{mg} / \mathrm{L}$. Water with chloride concentrations greater than
$1,500 \mathrm{mg} / \mathrm{L}$ can injure or kill most plants, including citrus (Campbell and others, 1984: Schiner and others, 1988).

A sharp increase in chloride concentration commonly occurs over a distance of a few tens of feet between the freshwater in the Upper Floridan aquifer and the saltier water in the Lower Floridan aquifer. Chloride concentrations in water samples collected during reverse air drilling of well 12, a test well near Okeechobee, increased from 140 to $1,600 \mathrm{mg} / \mathrm{L}$ between the depths of 1,277 and $1,308 \mathrm{ft}$ below land surface, a distance of $31 \mathrm{ft}$ (CH2M-Hill, 1989).

Packer test results indicated the same change in water quality in the well. Completion reports for wells which were backplugged because they were producing salty water indicate similar conditions in other parts of the county.

Two major requirements for wells supplying water for extensive agricultural activities are highyield capability and good-quality water. To maximize volume and water quality, wells commonly are designed to penetrate the maximum thickness of the aquifer that produces usable water. Three factors commonly considered in well design in Okeechobee County are (1) well yields that increase with depth below the Upper Floridan aquifer, (2) chloride concentrations that increase with depth throughout the county, and (3) the potential effects of heavy pumping that may cause upconing of saltwater.

The estimated depth below land surface to brackish water within the Floridan aquifer system was determined by analysis of depths of wells that were backplugged to reduce chloride concentrations, by fluid-resistivity logs of wells that tap both the Upper and Lower Floridan aquifers, and by water-quality samples from wells with known depths (fig. 22). Depth to brackish water in the Floridan aquifer system probably exceeds $1,200 \mathrm{ft}$ below land surface in the northwestern part of the county. There is no freshwater available in the Floridan aquifer system in the south-central part of the county around the city of Okeechobee.

Fluid-resistivity logs can indicate where highly mineralized water is entering the borehole of a well, such as in the resistivity $\log$ from well 27 shown in figure 23. Well 27, that taps the intermediate confining unit and the Upper and Lower Floridan aquifers, is in a discharge area of the county and was flowing at land surface during the logging. Two brackish-water inflow zones are indicated by the well 


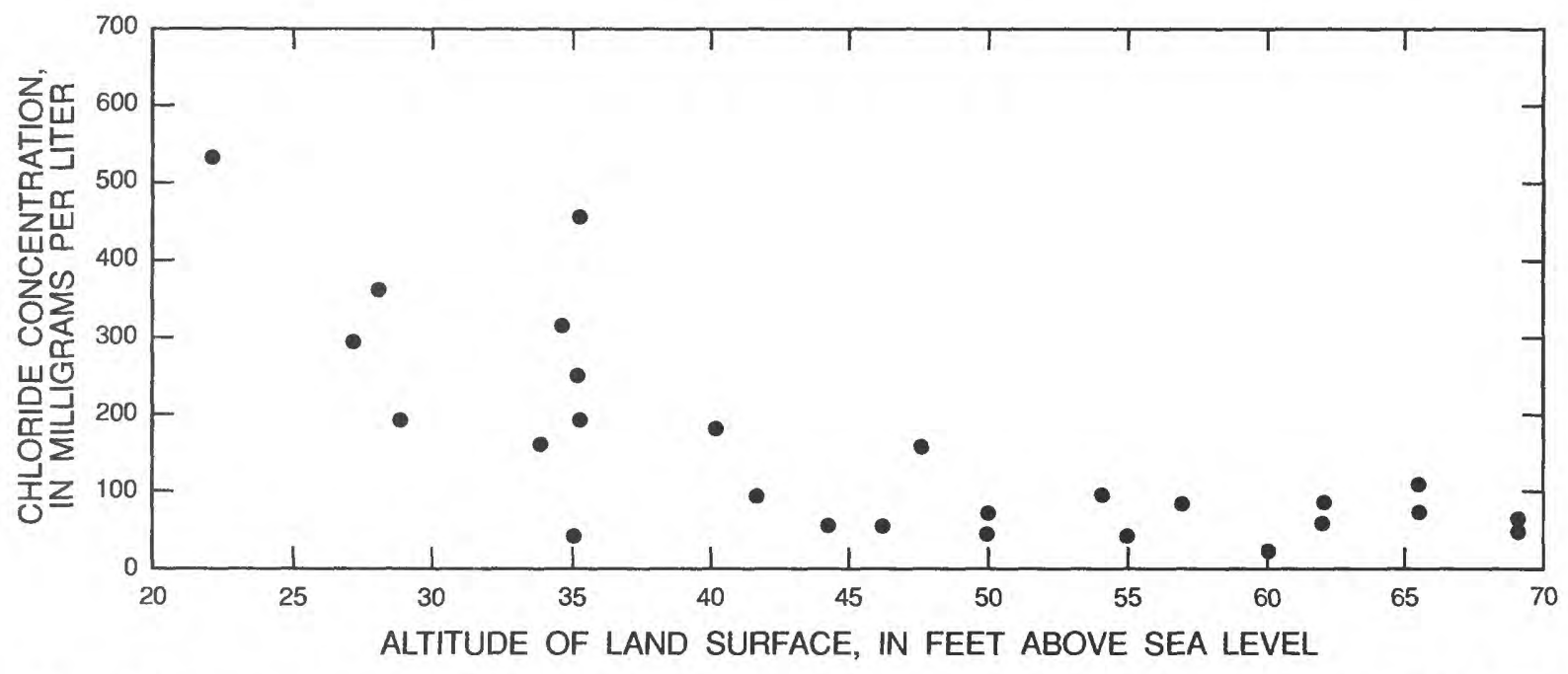

Figure 19. Relation between land-surface altitude and chloride concentrations in water from wells that tap the Upper Floridan aquifer, Okeechobee County, Fla.

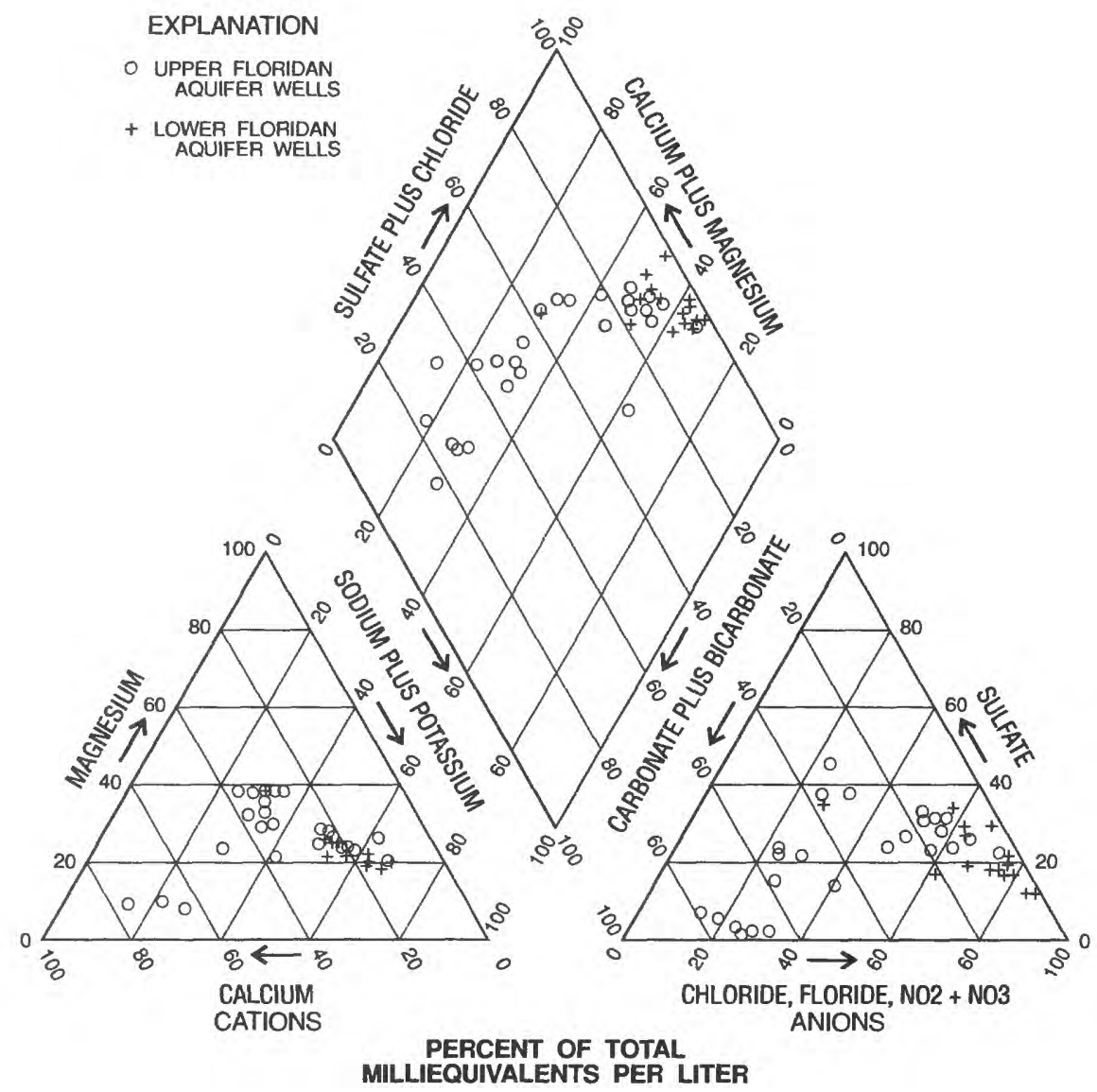

Figure 20. Chemical composition of water from wells that tap the Floridan aquifer system, Okeechobee County, Fla. 


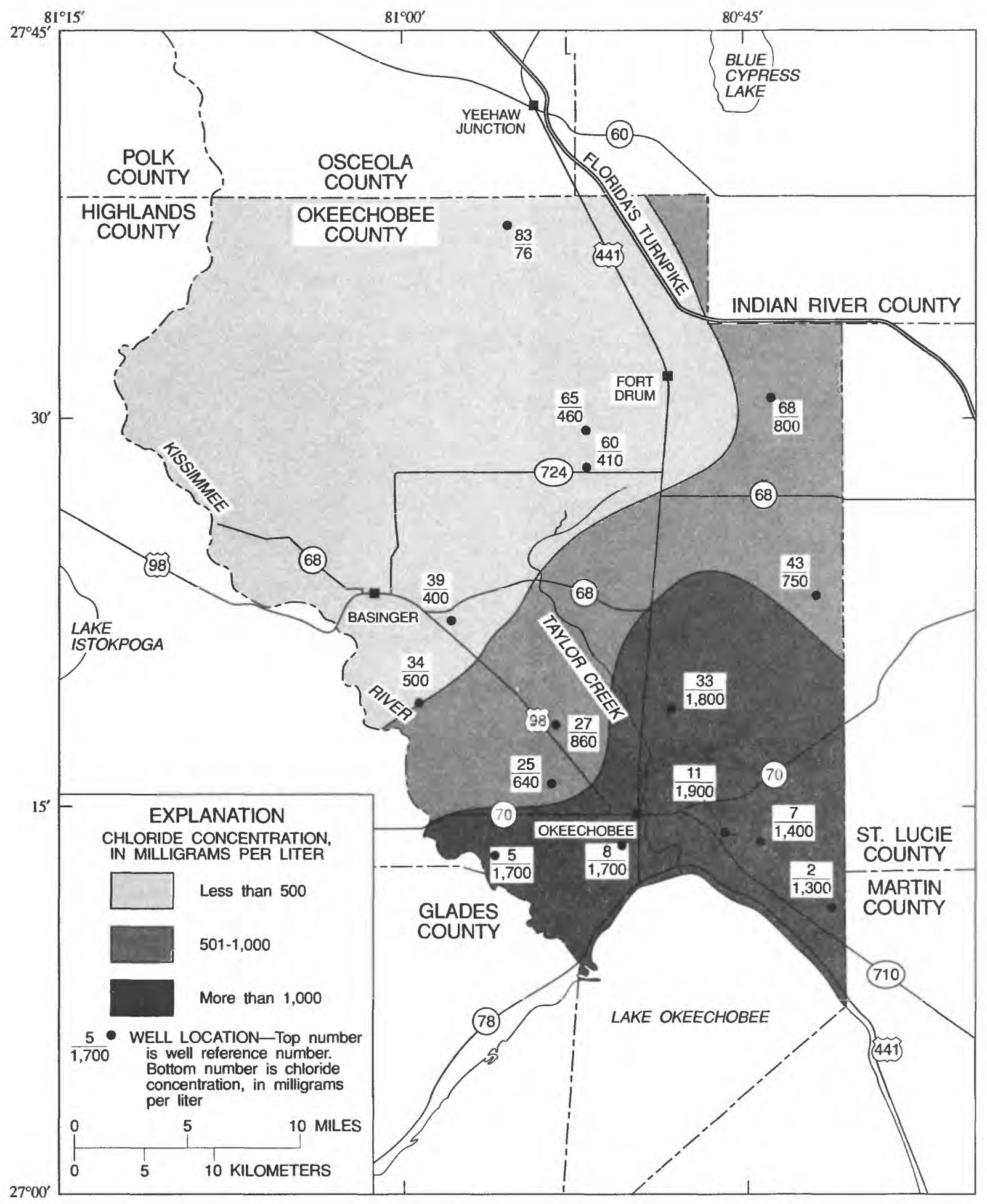

Figure 21. Chloride concentrations in water from wells that tap the Upper and Lower Floridan aquifers, Okeechobee County, Fla. 


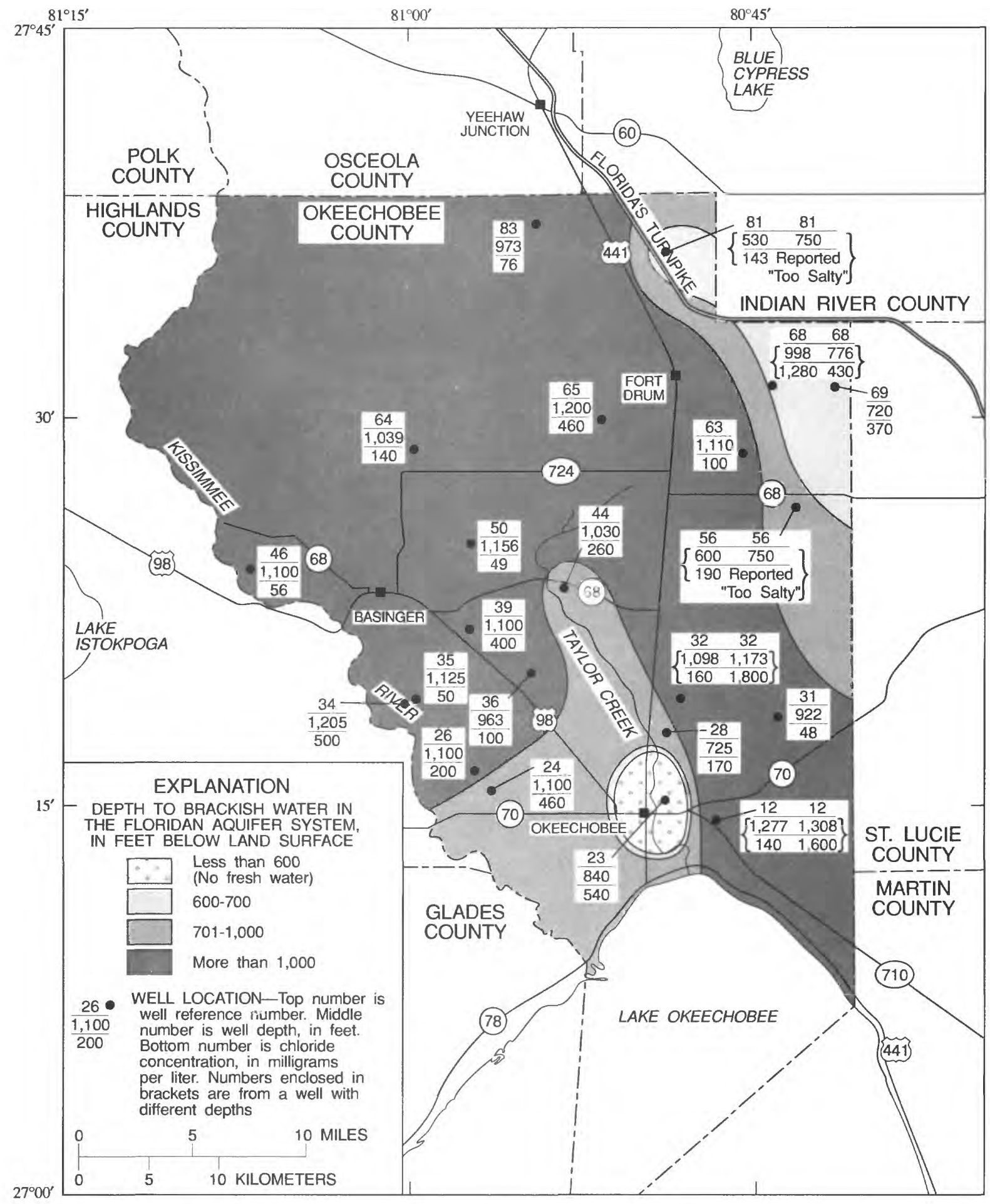

Figure 22. Depth to brackish water in the Floridan aquifer system (chloride concentration greater than 250 milligrams per liter). 


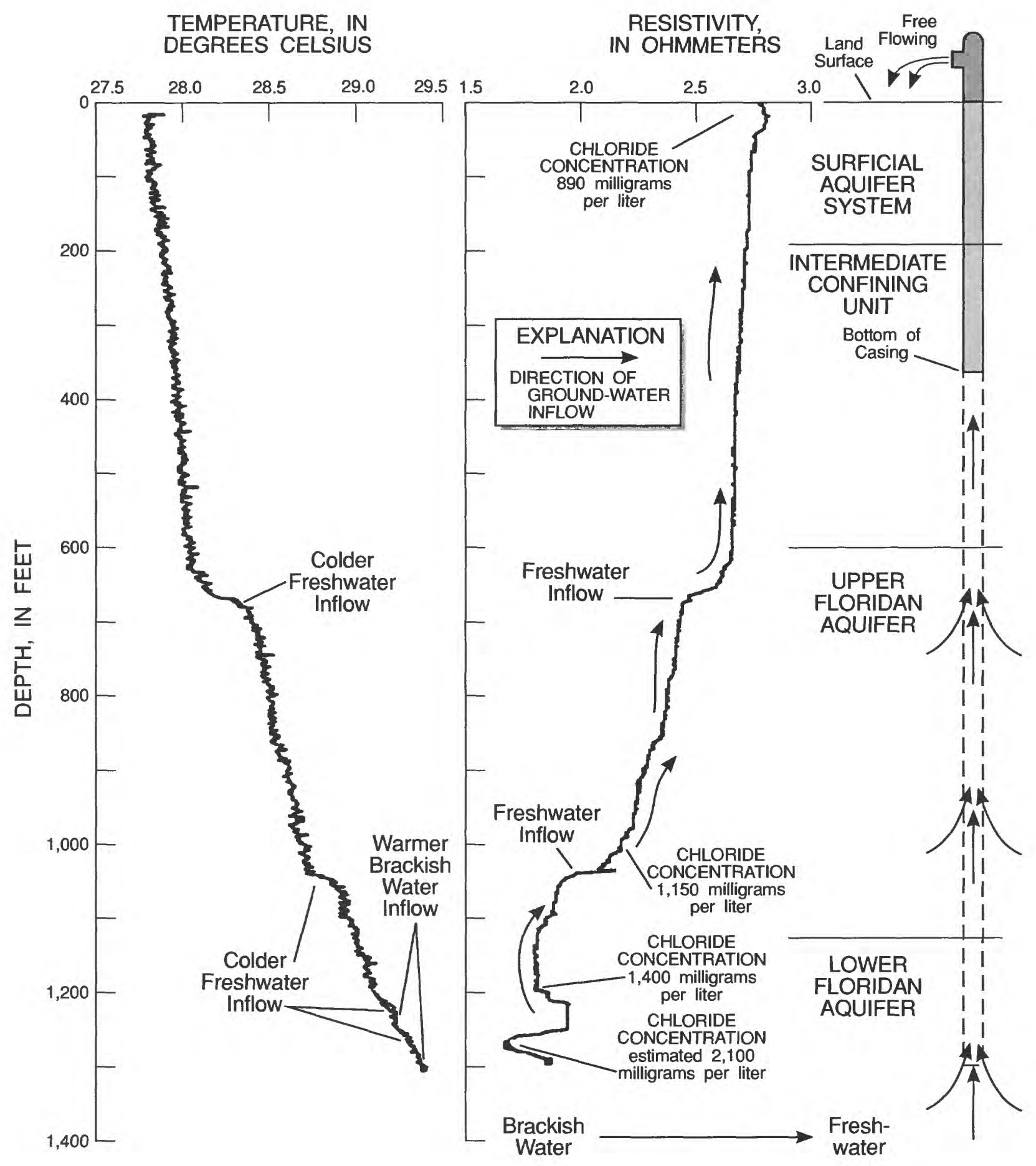

Figure 23. Temperature, chloride concentration (in milligrams per liter), and resistivity of water from well 27 that taps the intermediate confining unit and the Upper and Lower Floridan aquifers. (Well location shown in fig. 5). 
log--one at about $1,300 \mathrm{ft}$ and the other at $1,225 \mathrm{ft}$ below land surface. Four freshwater inflow zones also are indicated at about $1,250 \mathrm{ft}, 1,200 \mathrm{ft}, 1,040 \mathrm{ft}$, and $660 \mathrm{ft}$ below land surface. The well yield is a mixture of freshwater and brackish-water inflows, however, the ratio of freshwater inflow to brackishwater inflow is too low to yield composite water with less than $250 \mathrm{mg} / \mathrm{L}$ chloride concentration. Backplugging this well from $1,300 \mathrm{ft}$ to about $1,050 \mathrm{ft}$, just below the third zone of freshwater inflow, might substantially reduce the chloride concentration in water from this well.

Wells in several areas of the county have been successfully backplugged to reduce brackish inflow. Most of these wells either tapped the Lower Floridan aquifer or were finished just above it; the upconing of brackish water may have occurred in response to well discharge. Well 32, backplugged from 1,173 to $1,098 \mathrm{ft}$ in 1986 , previously yielded water containing chloride concentrations greater than $1,800 \mathrm{mg} / \mathrm{L}$. After backplugging, the well yielded water with chloride concentrations of about $160 \mathrm{mg} / \mathrm{L}$.

\section{Water-quality trends}

The quality of water from the Floridan aquifer system in Okeechobee County probably has not deteriorated as a result of man's influence, except in localized areas where heavy agricultural pumping and interborehole flow in deep wells has caused upward movement of the saltwater interface. Wells used in exploration for oil and minerals were drilled in Okeechobee County in the early 1900 's, but records from these wells are unavailable. A few of these wells were converted to watersupply wells for industrial use or drinking water. The earliest documentation of the quality of water from these wells (Stringfield, 1933) indicates nonpotable water in the area around the city of Okeechobee in 1933. Available historical records indicate that other wells in this area typically yielded water with chloride concentrations greater than $250 \mathrm{mg} / \mathrm{L}$. However, these data may be biased because much of the data are from early fieldreconnaissance efforts in southern Okeechobee County where high chloride concentrations commonly are present in water in the Floridan aquifer system.

A comparison of records for several wells from the 1950 's to the present indicates no noticeable increase in chloride concentrations in water from these wells. Longterm data for well 22 near the city of Okeechobee indi- cates that chloride concentrations have decreased slightly in recent years (fig. 24). One possible explanation for the decrease may be the reduced flow rate caused by the long-term decline in the potentiometric surface and less drawdown in this free-flowing well. Because the drawdown is reduced, the upconing of brackish water also is reduced, thus lowering the composite chloride concentration of water discharged from the well.

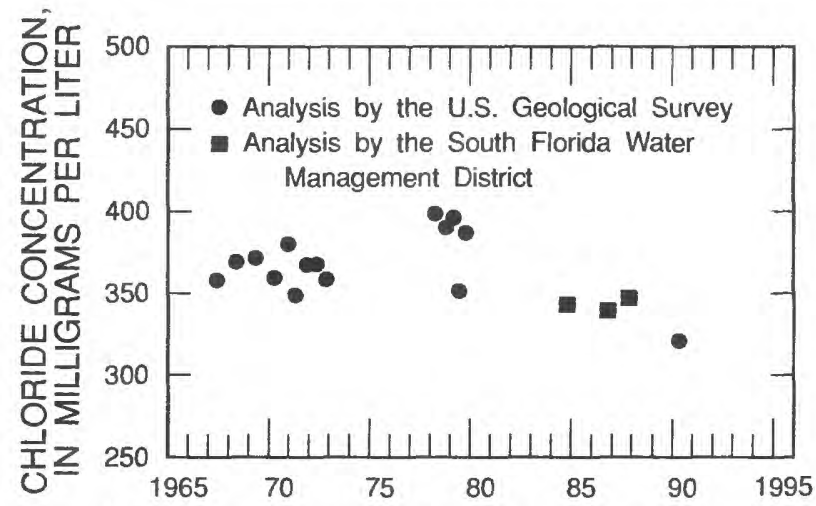

Figure 24. Chloride concentrations in water from well 22. (Well location shown in fig. 5).

\section{SUMMARY AND CONCLUSIONS}

Continued population growth in Okeechobee County probably will increase demand for potable water. The surficial and Floridan aquifer systems are the sources of ground water used in the county. Substantial withdrawals are made from the Floridan aquifer system for irrigation, livestock, and public supply. The surficial aquifer system is used mostly for domestic and public supply and also for agriculture.

The county is poorly drained and most of the area is marshland. Many truck-farming and pasture-grazing areas have been drained by ditches, canals, and shallow swales. Natural drainage occurs within four major drainage basins: the St. Johns River, the Kissimmee River, Taylor Creek to Lake Okeechobee, and the St. Lucie-Martin County basins.

Mean annual rainfall for the county ranges from 46 to 49 inches per year. The maximum potential evaporation ranges from 48 to 50 inches per year. The minimum evapotranspiration rate for the county probably is between 35 and 48 inches per year.

The occurrence, movement, availability, quality, and quantity of ground water in the county are related to geology. The study area is underlain mostly by layers of 
sand, shell, clay, limestone, dolomite, gypsum, anhydrite, and shale. The surficial aquifer system, consisting of undifferentiated deposits of sand, silt, fine to coarse shell, and clay, is separated from the Floridan aquifer system by the sands, silts, and dense clays of the intermediate confining unit. The Floridan aquifer system in Okeechobee County is composed of the Suwannee Limestone, where present, the Ocala Limestone, and the Avon Park and Oldsmar Formations.

Wells that tap the surficial aquifer system, which is composed of undifferentiated sand, silt, and shell, commonly have specific capacities of about 10 gallons per minute per foot of drawdown. Specific capacities tend to be highest in wells that tap thick sand and shell layers of the middle permeable zone.

The water-table surface in the surficial aquifer system ranges from land surface to about 10 feet below land surface in the county. Annual fluctuations in the water-table surface average about 4 feet. The aquifer system is recharged by infiltration of rainfall and downward percolation of irrigation water. In some areas of the county, surface discharge from freeflowing wells completed in the Floridan aquifer system recharges the surficial aquifer system.

Water in the surficial aquifer system generally is fresh, although high concentrations of iron, chloride, and dissolved solids cause problems for water users in some areas. In several areas of the county brackish water is present in the surficial aquifer system. These areas of elevated chloride concentrations generally are located near free-flowing Floridan aquifer system wells.

The top of the Floridan aquifer system is about 350 feet below land surface in the northern part of the study area and dips to about 730 feet below land surface in the southeastern part of the county. The Floridan aquifer system has two major water-bearing zones in Okeechobee County: the Upper Floridan and Lower Floridan aquifers. The Upper Floridan aquifer consists of fairly dense limestone and dolomite, and is less productive in Okeechobee County than in most other areas of the State. The Lower Floridan aquifer has three distinct zones of high permeability; however, wells that tap these zones yield brackish water.

The potentiometric surface of the Upper Floridan aquifer has declined about 10 feet since the 1930's.

Seasonal fluctuations (from dry to wet seasons) in the potentiometric surface range from 1 to 4 feet.

The rate of recharge to the Floridan aquifer system in Okeechobee County is low, ranging from 0.2 to 1.0 inch per year, or a maximum of about
50,000 gallons per day per square mile in recharge areas. Almost half the county is a discharge area; rates of diffuse upward leakage range from 0.4 to 13 inches per year in these discharge areas.

Transmissivities of the Upper Floridan aquifer generally are low, with most test results yielding values less than 10,000 feet squared per day. Transmissivity values in the northeastern part of the county tend to be higher. Tests on wells that tap the Lower Floridan aquifer indicate that the transmissivity of that zone may be as high as 600,000 feet squared per day. Yields of wells that tap the Floridan aquifer system range from 50 to 6,500 gallons per minute.

The quality of water in the Floridan aquifer system varies areally within Okeechobee County, but generally has remained fairly constant with time. The major water-quality problem in the Floridan aquifer system in Okeechobee County is the presence of brackish water. Areas of elevated dissolved-solids, chloride, and sulfate concentrations in water from the Upper Floridan aquifer occur in the northeastern corner and in the south-central part of the county. Wells that tap the Upper Floridan aquifer in recharge areas tend to yield water that is a calcium bicarbonate type, whereas wells in discharge areas tend to yield water that is either a magnesium sulfate type or a sodium chloride type.

Chloride concentrations are greater than 250 milligrams per liter in water from most wells that tap the Lower Floridan aquifer. Some of the Lower Floridan aquifer wells yield water that has chloride concen-trations that exceed 1,500 milligrams per liter which can be detrimental to citrus and other plants. There is usually a sharp interface (within tens of feet) between the freshwater in the Upper Floridan aquifer and the saltier water in the Lower Floridan aquifer.

Depth to brackish water in the Floridan aquifer system exceeds 1,200 feet below land surface in some areas of the northwestern part of the county. "Skimmer wells" that tap the top 100 to 200 feet of the Upper Floridan aquifer can yield freshwater in some areas that have brackish water at greater depths in the aquifer. The Floridan aquifer system contains no freshwater in an area around the city of Okeechobee.

Backplugging of some wells that tap the Lower Floridan aquifer has been used to reduce the high chloride concentrations in water from these wells. However, backplugging of wells usually reduces the flows from these wells. Three factors commonly are considered in the design of high-yield wells for agriculture use: (1) yields commonly increase with 
depth in the Upper Floridan aquifer and can be maximized by tapping the full thickness of the aquifer that produces water of suitable quality ; (2) chloride concentration increases with depth in the Floridan aquifer system throughout the county; and (3) heavy pumping may cause upconing of saltwater and results in water-quality degradation

The quality of water from the Floridan aquifer system probably has not deteriorated because of man's influence, except in localized areas where heavy agricultural pumping and interborehole flow in deep wells has caused upward movement of saltwater. Nonpotable water in the Upper Floridan aquifer in the city of Okeechobee was documented as early as 1933.

Long-term data for a well near the city of Okeechobee indicate that chloride concentrations appear to have decreased slightly in recent years.

\section{SELECTED REFERENCES}

Bradner, L.A., 1987, Potentiometric surface of the Upper Floridan aquifer in the St. Johns River Water Management District and vicinity, Florida, September 1987: U.S. Geological Survey Open-File Report 87-688, 1 sheet.

Brown, M.P., 1980, Aquifer recovery test data and analyses for the Floridan aquifer system in the Upper East Coast planning area, South Florida Water Management District: West Palm Beach, South Florida Water Management District Technical Publication 80-1, 52 p.

Bush, P.W., and Johnston, R.H., 1988, Ground-water hydraulics, regional flow, and ground-water development of the Floridan aquifer system in Florida and in parts of Georgia, South Carolina, and Alabama: U.S. Geological Survey Professional Paper 1403-C, $80 \mathrm{p}$.

Campbell, Dean, Munch, D.A., Johnson, Richard, Parker, M.P., Parker, Bruce, Rao, D.V., Marella, Richard, and Albanesi, Edward, 1984, Section III, Water administration and regional management, Chapter 13, St. Johns River Water Management District, in Fernald, E.A., and Patton, D.J., eds., Water Resources Atlas of Florida, Tallahassee, Florida State University, p. 158-177.

CH2M-Hill, Inc., 1989, Construction and testing of the Aquifer Storage Recovery (ASR) demonstration project for Lake Okeechobee, Florida, Deerfield Beach, Fla., Volumes I, II, and III.
Ferris, J.G., Knowles, D.B., Brown, R.H., and Stallman, R.W., 1965, Theory of aquifer tests: U.S. Geological Survey Water-Supply Paper 1536-E, 173 p.

Florida Department of State, 1989, Rules of the Florida Department of Environmental Regulation, public drinking water systems: Tallahassee, Florida, Chapter 17-550, in Florida Administrative Code, 45 p.

Hem, J.D., 1985, Study and interpretation of the chemical characteristics of natural water: U.S. Geological Survey Water-Supply Paper 2254, 263 p.

Herr, J.W., and Shaw, J.E., 1989, South Florida Water Management District ambient ground-water quality: West Palm Beach, South Florida Water Management District Technical Publication 89-1, 12 p., 16 supps., apps. 1-16.

Hydrodesigns, Inc., 1988, Safe casing depths for Floridan aquifer system wells in Martin, St. Lucie, and Okeechobee Counties, Florida, Juno Beach, 87 p., apps.

Marella, R.L., 1988, Water withdrawals, use, and trends in Florida, 1985: U.S. Geological Survey WaterResources Investigations Report 88-4103, 43 p.

Meyer, F.W., 1989, Hydrogeology, ground-water movement, and subsurface storage in the Floridan aquifer system in southern Florida: U.S. Geological Survey Professional Paper 1403-G, 59 p.

Miller, J.A., 1986, Hydrogeologic framework of the Floridan aquifer system in Florida and parts of Georgia, Alabama, and South Carolina: U.S. Geological Survey Professional Paper 1403-B, 91 p.

NOAA, 1947-90, Climatological data, Florida annual summaries.

Navoy, A.S., and Bradner, L.A., 1987, Ground-water resources of Flagler County, Florida: U.S. Geological Survey Water-Resources Investigations Report 87-4021, 45 p.

Ostlund, H.G., and Dorsey, H.G., 1977, Rapid electrolytic enrichment and hydrogen gas proportional counting of tritium, in Low-Radioactivity Measurements and Applications, Proceedings of the International Conference on Low-Radioactivity Measurements and Applications, the High Tatras, Czechoslovakia, October 6-10, 1975: Slovenske Pedagogicke Nakladatel'stvo, Bratislava.

Parker, G.G., Ferguson, G.E., Love, S.K., and others, 1955, Water resources of southeastern Florida: U.S. Geological Survey Water-Supply Paper 1255, 965 p.

Purdum, E.D., and Anderson, J.R., Jr., project directors, 1988, Florida County atlas and municipal facts book: Institute of Science and Public Affairs, Tallahassee, Florida State University, 145 p. 
Reese, D.E., Belles, R.B., and Brown, M.P., 1984, Hydrogeologic data collected from the Kissimmee Planning Area, South Florida Water Management District: West Palm Beach, South Florida Water Management District Technical Publication 84-2. $191 \mathrm{p}$.

Schiner, G.R., Laughlin, C.P., and Toth, D.J., 1988, Geohydrology of Indian River County, Florida: U.S. Geological Survey Water-Resources Investigations Report 88-4073, $110 \mathrm{p}$.

Shaw, J.E., and Trost, S.M., 1984a, Hydrogeology of the Kissimmee Planning Area, South Florida Water Management District, pt. 1, Text: West Palm Beach, South Florida Water Management District Technical Publication 84-1, DRE-188, $235 \mathrm{p}$.

1984b, Hydrogeology of the Kissimmee Planning Area, South Florida Water Management District, pt. 2, Appendices: West Palm Beach, South Florida Water Management District Technical Publication 84-1, DRE-189, 251 p., apps. I-VI.

Southeastern Geological Society Ad Hoc Committee on Florida Hydrostratigraphic Unit Definition, compiler, 1986, Hydrogeological units of Florida: Florida Bureau of Geology Special Publication no. 28, 9 p.

Spechler, R.M., Murray, L.C., Bradner, L.A., and Phelps, G.G., 1991, Potentiometric surface of the upper Floridan aquifer in the St. Johns River Water Management District and vicinity, September 1990: U.S. Geological Survey Water-Resources Investigations Open-File Report 91-190, 1 sheet.

Sprinkle, C.L., 1982, Chloride concentration in water from the upper permeable zone of the Tertiary limestone aquifer system, southeastern United States: U.S. Geological Survey Water-Resources Investigations Open-File Report 81-1103, 1 sheet.

Stringfield, V.T., 1933, Ground water in the Lake Okeechobee area, Florida: Florida Geological Survey Report of Investigations no. 2, 31 p.
1936, Artesian water in the Florida peninsula: U.S. Geological Survey Water-Supply Paper 773-C, p. 115-195.

1966, Artesian water in Tertiary limestone in the Southeastern States: U.S. Geological Survey Professional Paper 517, 226 .

Swancar, Amy, and Hutchinson, C.B., 1992, Potential for the contamination of the Upper Floridan aquifer, westcentral Florida: U.S. Geological Survey Open-File Report 92-47, 21 p.

Theis, C.V., 1935, Relation between the lowering of the piezometric surface and the rate and duration of discharge to a well using ground-water storage: American Geophysical Union Transactions, pt. 2, p. 519-524; (Duplicated as U.S. Geological Survey Ground-Water Note 5, 1952)

Tibbals, C.H., 1978, Effects of paved surfaces on recharge to the Floridan aquifer in east-central Florida--A conceptual model: U.S. Geological Survey WaterResources Investigations Report 78-76, 42 p.

-1981 , Computer simulation of the steady-state flow system of the Tertiary limestone (Floridan) aquifer system in east-central Florida: U.S. Geological Survey Water-Resources Investigations Open-File Report 81-681, 31 p., 9 sheets.

1990, Hydrology of the Floridan aquifer system in east-central Florida: U.S. Geological Survey Professional Paper 1403-E, 98 p.

University of Florida, 1991, Florida population: Census summary 1990: Gainesville, Bureau of Economic and Business Research, 55 p.

Visher, F.N., and Hughes, G.H., 1975, The difference between rainfall and potential evaporation in Florida, ( $2 \mathrm{~d}$ ed.): Florida Bureau of Geology Map Series 32, 1 sheet.

White, W.A., 1970, The geomorphology of the Florida peninsula: Florida Bureau of Geology Bulletin 51, $164 \mathrm{p}$. 